\title{
Partial revision of the neustonic genus Scapholeberis Schoedler, 1858 (Crustacea: Cladocera): decoding of the barcoding results
}

\author{
Petr G Garibian $^{\text {Equal first author, } 1}$, Anna N Neretina ${ }^{1}$, Derek J Taylor ${ }^{2}$, Alexey A Kotov ${ }^{\text {Corresp. Equal first author, } 1}$ \\ ${ }^{1}$ A.N. Severtsov Institute of Ecology and Evolution, Russian Academy of Sciences, Moscow, Russia \\ 2 Department of Biological Sciences, State University of New York at Buffalo, Buffalo, New York, United States \\ Corresponding Author: Alexey A Kotov \\ Email address: alexey-a-kotov@yandex.ru
}

Water fleas (Crustacea: Cladocera) are among the most intensively studied freshwater invertebrates. But, ecologically important daphniids that live on the surface layer (neuston) remain taxonomically confused. Here we attempt to reconcile genetic and morphological information for the neustonic genus Scapholeberis Schoedler, 1858 (Cladocera: Daphniidae) and present the first revision of the Scapholeberis kingii species group. We analyzed new and existing mitochondrial DNA sequences (cytochrome $C$ oxidase subunit I gene region) together with morphology for all but one of the known species of this neustonic daphniids genus. Morphological comparisons of available populations, belonging to the Scapholeberis kingii species group from several Australian, Asian and African localities, revealed, that they are almost identical according to parthenogenetic females. At the same time, Australian populations can be reliably distinguished from Asian ones based on the morphology of gamogenetic females. Mitochondrial DNA data analyses revealed divergent lineages ( $>17 \%$ for the DNA barcoding COI region) for the three different species (Australia, Asia and Africa). Based on this set of data, we redescribed S. kingii Sars, 1888 from Australia, its terra typica, and described a new species, S. smirnovi sp.nov. from the Russian Far East, Korea and Japan. The status of populations from Ethiopia and the Republic of South Africa remained unclear, because in the African material and the putative type material, we found only parthenogenetic females. Our results provide an integrative revision of the $S$. kingii species group and improve the taxonomic scaffold used for barcoding and genomics for the remaining species groups in the daphniid genus Scapholeberis. 


\section{Partial revision of the neustonic genus Scapholeberis}

\section{Schoedler, 1858 (Crustacea: Cladocera): decoding of the}

\section{3 barcoding results}

4

5 Petr G. Garibian ${ }^{1 *}$, Anna N. Neretina ${ }^{1}$, Derek J. Taylor ${ }^{2}$, Alexey A. Kotov ${ }^{1 *}$

6

$7{ }^{1}$ A.N. Severtsov Institute of Ecology and Evolution, Russian Academy of Sciences, Moscow, 8 Russia.

$9{ }^{2}$ Department of Biological Sciences, the State University of New York at Buffalo, Buffalo, 10 USA.

* Equal first authors

14 Corresponding author: Alexey A. Kotov ${ }^{1}$

15 A.N. Severtsov Institute of Ecology and Evolution, Moscow, Russia Leninsky prospect 33,

16 Moscow, 119071, Russia

17 alexey-a-kotov@yandex.ru

\section{Abstract}

Water fleas (Crustacea: Cladocera) are among the most intensively studied freshwater

21 invertebrates. But, ecologically important daphniids that live on the surface layer (neuston)

22 remain taxonomically confused. Here we attempt to reconcile genetic and morphological 
23 information for the neustonic genus Scapholeberis Schoedler, 1858 (Cladocera: Daphniidae) and

24 present the first revision of the Scapholeberis kingii species group. We analyzed new and

25 existing mitochondrial DNA sequences (cytochrome $\mathrm{C}$ oxidase subunit I gene region) together

26 with morphology for all but one of the known species of this neustonic daphniids genus.

27 Morphological comparisons of available populations, belonging to the Scapholeberis kingii

28 species group from several Australian, Asian and African localities, revealed, that they are

29 almost identical according to parthenogenetic females. At the same time, Australian populations

30 can be reliably distinguished from Asian ones based on the morphology of gamogenetic females.

31 Mitochondrial DNA data analyses revealed divergent lineages ( $>17 \%$ for the DNA barcoding

32 COI region) for the three different species (Australia, Asia and Africa). Based on this set of data,

33 we redescribed S. kingii Sars, 1888 from Australia, its terra typica, and described a new species,

34 S. smirnovi sp.nov. from the Russian Far East, Korea and Japan. The status of populations from

35 Ethiopia and the Republic of South Africa remained unclear, because in the African material and

36 the putative type material, we found only parthenogenetic females. Our results provide an

37 integrative revision of the S. kingii species group and improve the taxonomic scaffold used for

38 barcoding and genomics for the remaining species groups in the daphniid genus Scapholeberis.

39 Subjects: Biodiversity, Taxonomy, Freshwater Biology

40

Running title

42

An integrative revision of the neustonic genus Scapholeberis

43

44

Introduction

45 
Integrative taxonomy combines the evidence from disparate biological disciplines to

47 better understand biodiversity. This approach has been particularly fruitful for taxonomically challenging, yet well-studied aquatic groups such as the water fleas (Crustacea: Branchiopoda: Cladocera). For some cladoceran taxa successful advances have been made by morphological (Smirnov, 1992, 1996; Van Damme, Sinev \& Dumont, 2011; Neretina \& Sinev, 2016) or genetic evidence alone (Adamowicz et al., 2009; Bekker et al., 2016; Thielsch et al., 2017). For some problematic cladoceran taxa, a combination of approaches has resulted in taxonomic progress (Belyaeva \& Taylor, 2009; Kotov, Ishida \& Taylor, 2009; Quiroz-Vázquez \& Elías-Gutiérrez, 2009; Sinev, Karabanov, Kotov, 2020). The integrative approach has been particularly useful for taxa that lack distinguishing characters for parthogenetic females. For cladocerans, the sexual stages appear sporadically, but can be a rich source of diagnostic morphological characters (see review in Kotov, 2013). Genetic approaches, such as formal genetic barcoding (Hebert et al., 2003), have much value for the discovery of novel lineages and taxonomic diagnoses. However, taxonomic advances with genetic information alone are problematic because the existing taxonomic scaffold (i.e. from the 19th of 18th centuries) is based on morphology (Kotov \& Gololobova, 2016; Dupérré, 2020). Moreover, as museum samples, including type materials, are generally not amenable to genetic study (but see Umetsu et al., 2002; Turko et al., 2019), taxonomic advances are often limited to morphological evidence. other organisms) from different geographic regions are rapidly accumulating in specialized databases such as GenBank (Benson et al., 2012). A massive accumulation of cytochrome C oxidase subunit I gene regionregion sequences (COI data) is available for many taxa due to the successful realization of the Barcoding of Life initiative (Hebert et al., 2003). The coordination 
69 of this genetic information with formal taxonomic knowledge, even with the modest aim of

70 accurate species identifications, is a considerable challenge.

71 The aim of the present paper is to apply the integrative approach to the taxonomic

72 problems of cladocerans associated with the surface layer of standing waters, with a focus on the 73 genus Scapholeberis Schödler, 1858 (Anomopoda: Daphniidae: Scapholeberinae). Since the

74 revision of Dumont \& Pensaert (1983), most efforts to understand the diversity within this genus

75 have been local (Hudec, 1983; Elmoor-Loureiro, 2000; Elías-Gutiérrez et al., 2008; Quiroz-

76 Vázquez \& Elías-Gutiérrez, 2009; Hudec, 2000; Kotov, Jeong \& Lee, 2012; Andrade-Sossa,

77 Buitron-Caicedo \& Elías-Gutiérrez, 2020). Recently, a global phylogenetic study of the

78 subfamily based of 402 multigene sequences from the 12S rRNA, 16S rRNA, and tRNA (val)

79 regions of the mitochondrial genomes was carried out (Taylor, Connelly \& Kotov, 2020). This

80 study revealed an unexpectedly high lineage diversity in the Eastern Palearctic. Other regions,

81 such as Africa, remained unexamined according to current standards of cladoceran taxonomy.

82 Notably, the within-genus divergences for neustonic taxa were much greater than that found

83 within other daphniid genera (Taylor, Connelly \& Kotov, 2020). We were unable to reconcile the

84 newly uncovered taxa with existing databases, genome projects, and taxonomy or to assess if the

85 marked divergences were limited to non-protein coding regions. Here we address some

86 geographic sampling gaps (such as Africa), attempt to unify the genetic (including DNA

87 barcoding and genome projects) and morphological knowledge, and revise the taxonomy of the

88 genus Scapholeberis. We collect new COI sequences and revise the taxonomy of the widespread

89 and historically confused Scapholeberis kingii Sars, 1888 species group using an integrated

90 approach. 
92

93

94

95

96

97

\section{Material and methods}

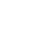

\section{Collecting samples and their preliminary analysis}

Numerous samples from different localities in different continents were collected by our team or by our colleagues via small-sized plankton nets (with mesh size $50 \mu \mathrm{m}$ ) and fixed with $4 \%$ formaldehyde or $96 \%$ ethanol in the fields, immediately after sampling. Sampling in nonprotected water bodies of Russia does not require special permissions. Sampling in South Korea was conducted in frames of the program of the National Institute of Biological Resources (NIBR), of the Republic of Korea. Sampling in Ethiopia was conducted in frames of work of the Joint Ethiopian-Russian Biological Expedition (JERBE), with permission from the Ministry of Environment of Ethiopia to JERBE. Samples from Australia were obtained from colleagues having appropriate permissions.

All samples were preliminarily examined using a stereoscopic microscope. Individuals of Scapholeberis in them were initially identified via available references only according to morphological features (mainly, shape of head and rostrum from the ventral view) (Dumont \& Pensaert, 1983; Kotov et al., 2010).

\section{Genetics}

Before genetic analysis, identification of each parthenogenetic female was re-checked under a binocular stereoscopic microscope in order to avoid mistakes, because some samples contained several Scapholeberis species simultaneously. Selected individuals were placed into 96-well PCR plates and dried from ethanol on air. DNA of single individuals was extracted using DNA QuickExtract (Epicenter) as modified by Ishida, Kotov \& Taylor (2006). PCR reactions 
115 were carried out in $25 \mu \mathrm{L}$ or $50 \mu \mathrm{L}$ volumes using the Promega GoTaq Master mix protocol with

$1165 \mu \mathrm{L}$ of DNA extraction using HCO/LCO primers of Folmer et al. (1994). PCR cycling

117 conditions were $95^{\circ} \mathrm{C}$ for $2 \mathrm{~m}, 95^{\circ} \mathrm{C}$ for $30 \mathrm{~s}, 48^{\circ} \mathrm{C}$ for $30 \mathrm{~s}$, and $72^{\circ} \mathrm{C}$ for $1 \mathrm{~m}$ for 39 cycles,

118 followed by $72{ }^{\circ} \mathrm{C}$ for $5 \mathrm{~m}$. The sizes of the PCR products were verified by agarose gel

119 electrophoresis. PCR products were then purified and sequenced by TACGEN (California).

120 Amplicons were sequenced in both directions and the contigs were assembled in Geneious R7.

121 The authenticity of newly obtained sequences was verified by BLAST comparisons. Additional

122 sequences were obtained from NCBI GenBank. The alignment was carried out in the online

123 version of MAFFT 7 using the default settings. Phylogenetic trees were estimated using a

124 Maximum Likelihood (ML) optimality criterion (with a GTR+I+gamma model) and the Subtree

125 Pruning and Regrafting branch-swapping algorithm in Seaview 4.7. Violin plots (which show the

126 full distribution of the data) were created in R for major taxa based on pairwise Kimura's 2-

127 parameter distances (also calculated in Seaview). Branch support for the ML tree was estimated

128 by the transfer bootstrap expectation method (using BOOSTER: https://booster.pasteur.fr/)

129 which typically shows less "false" erosion of support compared to nonparametric bootstrap for

130 deeper nodes (Lemonie et al., 2018). Bayesian analyses (BI) were performed in MrBayes v.3.2.6

131 (Ronquist et al., 2012). Four independent Markov chain Monte Carlo (MCMC) analyses were

132 run simultaneously for 100000 generations and sampled every 500 generations. The site rate

133 parameter (rates) was gamma plus invariable sites (invgamma) and the number of substitution

134 types (nst) was six. The first $25 \%$ of the generations were discarded as the burn-in. Phylograms

135 were visualized using the FigTree Version 1.4.4. The ML tree was rooted using specimens of the

136 genus Megafenestra as outgroups. 


\section{Morphological analysis}

141 The morphology of populations from Australia and Asia (southern part of the Russian Far

142 East and South Korea), containing both parthenogenetic and ephippial females, was examined in

143 detail with the aim of finding diagnostic characters. Only parthenogenetic females from Ethiopia

144 and the Republic of South Africa were examined because ephippial females and males were

145 lacking. Specimens of Scapholeberis from presorted samples were selected under a binocular

146 stereoscopic microscope LOMO, and then studied in toto under optical microscopes Olympus

147 BX41 or Olympus CX 41 in a drop of glycerol-formaldehyde or a glycerol-ethanol mixture.

148 Then at least two parthenogenetic females and two ephippial females (if available) from each

149 locality were dissected under a stereoscopic microscope for the study of appendages and

150 postabdomen. Drawings were prepared via a camera lucida attached to optical microscopes.

151 Several individuals from each population were dehydrated in a series of ethanol washes $(30,50$,

$15270,95 \%$ ) and 100\% acetone and then dried using hexamethyldisilazane (Laforsch \& Tollrian,

153 2000). Dried specimens were mounted on aluminium stubs, coated with gold in a S150A Sputter

154 Coater (Edwards, United Kingdom), and examined under a scanning electron microscope (Vega

1553 Tescan Scanning Electron Microscope, TESCAN, Czech Republic). We used a system of setae

156 enumeration by Kotov (2013), in cases of dubious homologies, the numbers are supplied by

157 question marks.

158

159

Abbreviations 
Abbreviations for collections: DAD, permanent slides from Collectio Dadayana, the

161 Hungarian Natural History Museum, Budapest, Hungary; MGU ML, Invertebrate Collection of

162 Moscow State University, Moscow, Russia; NIBR, collection of the National Institute of

163 Biological Resources, Inchon, South Korea.

164

Abbreviations in illustrations and text: $\mathrm{I}-\mathrm{V}$, thoracic limbs I-V; acs, accessory seta;

e1-e5, endites 1-5 of thoracic limbs; ejh, ejector hooks on limb I; epp, epipodite; ext, exopodite;

IDL, inner distal lobe; ODL, outer distal lobe; pep, preepipodite.

\section{Nomenclatural acts}

The electronic version of this article in Portable Document Format will represent a published work according to the International Commission on Zoological Nomenclature (ICZN), and hence the new names contained in the electronic version are effectively published under that

172 Code from the electronic edition alone. This published work and the nomenclatural acts it contains have been registered in ZooBank, the online registration system for the ICZN. The through any standard web browser by appending the LSID to the prefix http://zoobank.org/. The

\section{Results}


184 detected 21 main mitochondrial clades of Scapholeberinae (Figs. 1-2, and Supplementary Table

185 1). We used the clade labels proposed by Taylor, Connelly \& Kotov, 2020. Lineages novel to the

186 present study are labelled: X, Y, L2, J1-J4. Deep branches within Scapholeberis had low to

187 moderate support in the ML tree. In contrast, the differentiation of terminal taxa (species) was

188 well-supported, as was the separation of major morphologically-based species/species groups: $S$.

189 mucronata (clades A-C and X, green in Fig. 2), S. rammneri (clades F-H and Y, red), S. freyi

190 (clades J1-J4, black), S. kingii (clades K, L1, L2, grey), S. spinifera (clade M), and S. cf.

191 microcephala- armata (clades E and N) (Figs. 1 and 2).

192 The S. mucronata species group (Figs. 1 and 2) had four main geographic clades

193 (A+B+C+X). Clade A (S. mucronata s. str.) was detected only in Western and Central Europe;

194 clade B was detected from European Russia to Yakutia and Alaska; clade C was found in

195 Western Alaska only. Clade X was detected in the vicinity of Churchill, Manitoba (Jeffery,

196 Elías-Gutiérrez \& Adamowicz, 2011).

197 The S. rammneri species group (Figs. 1 and 2) had five main geographic clades

$198(\mathrm{~F}+\mathrm{G}+\mathrm{H}+\mathrm{I}+\mathrm{Y})$. Clade F (S. rammneri s.str.) was found in a single locality in Mongolia; clade $\mathrm{G}$

199 was present in two localities in Eastern Siberia; clade H was widely distributed in North America

200 and in a single locality in Patagonia; clade I was detected only in a single locality in Patagonia.

201 Clade Y was found in a single locality in Israel.

202 The S. freyi species group (Figs. 1 and 2) was represented by four main clades (J1-J4).

203 Clade J1 (S. freyi s.str.) was detected in many localities in North America; clade J2 (S.

204 duranguensis) was found in two localities in Mexico; clade J3 was found in three localities on

205 the Yucatan Peninsula (sequences of Elias-Gutiérrez et al., 2008 and Prosser, Martínez-Arce \& 
206 Elías-Gutiérrez, 2013); clade J4 was present in a single locality in Brazil (sequence directly

207 submitted to the GenBank and then described as S. yahuarcaquensis by Andrade-Sossa, Buitron-

208 Caicedo \& Elías-Gutiérrez, 2020 and found also in Amazon basin in Colombia) and a single

209 locality in Belgium (also a direct submission to the GenBank).

210 The S. microcephala-armata species group (Figs. 1 and 2) was represented by two main

211 clades, E from Alaska and Far east, and N from North America.

212 The S. kingii species group (Figs. 1 and 2) was represented by three clades (K, L1-L2).

213 Clade K (Scapholeberis kingii s. str.) was detected only in Australia; clade L1 was found in

214 Japan and China; clade L2 was found in a single locality in Ethiopia.

215 The genus Megafenestra (Figs. 1 and 2) was represented by three clades: clade O (M.

216 aurita s.str.) was found in Europe (Ukraine and Switzerland), clade P was present in Alaska

217 only; clade Q (M. nasuta s.str.) was present in New York State, USA.

218 Sequence pairs within each genus (Megafenestra and Scapholeberis) had maximum K2

219 parameter distances that exceeded 30\% (Fig. 3). Indeed, the mean pairwise sequence divergence

220 within Scapholeberis exceeded 20\%. Notably, pairwise sequence divergences within each major

221 species group had e exceeded $20 \%$ as well. The closest members of the $S$. kingii complex were

222 from Japan and Africa with a 17.4\% distance estimate (Fig. 2).The large divergences within

223 genera in DNA sequences were not accompanied by divergences in COI amino acid sequences.

224 The most common protein sequence for example was $>99 \%$ similar to that found in the genus

225 Daphnia (e.g. AAL08864.1). Synapomorphic amino acid substitutions in Scapholeberis

226 included: a glycine to an alanine for S. kingii (Australia), and an alanine to a serine for the $S$.

227 mucronata group, and a serine to an alanine in S. microcephala. 
Order Anomopoda Sars, 1865

235

Family Daphniidae Straus, 1820 up to $0.75 \mathrm{~mm}$ without mucro). Body with typical features of the genus (see Dumont \& Pensaert, 1983), relatively elongated. In lateral view, head relatively large, without keel. Rostrum relatively short and blunt. In ventral view posteroventral portion of head forms a three-lobed rostrum, due to a shallow depression at the insertion point of antenna I on each side, its middle lobe rounded, with minute frontal head pore. Dorsal head pores absent. Head and valves without short denticles, spines or protuberances. Ventral margin of valve straight. Posteroventral angle with short mucro. Adhesive ventral rim of valves modified into "sucker-plate" (in terms of located setae at anteriormost portion and several sparsely located setae at posterior portion near mucro. Inner surface of posterior margin with broad "hyaline membrane" extending posterior rim and "denticulated membrane" consisting of row of short setules along posterior rim. Five pairs of thoracic limbs, proportions between seta 1' and seta 2 of thoracic limb I are important for species identification. Ephippium with single egg and two longitudinal keels. 


\section{Scapholeberis kingii Sars, 1888}

Figures 4-9

255

256

Daphnia mucronata (Müller) in King, 1853, p. 255-265, fig. 6E.

Dumont, 1983, 105-106, P1. 3; Dumont \& Pensaert 1983, p. 24-25, Fig. 2: 3; Fig. 4: 4; Fig. VI:

1-2; P1. 1: 8; P1. 2: 4; Pl. 3: 5, 7, 9; Pl. 4: 1-7; P1. 5: 1-2, 4; Fig. 10: 3; P1. 6: 6-8; Fig. 12 Fig. 21 :

4 (partial); Smirnov, 1995, p. 5; Shiel \& Dickson, 1995, p. 35.

? Scapholeberis Kingi n. sp. in Sars, 1903, p. 8-10, P1. 1: Fig. 2a-c. - junior homonym of

S. kingi Sars, 1888.

Type locality. "South Creek" and "Paramatta" (King, 1853), New South Wales,

265

266

267

268

269

270

271

272

273 Scapholeberis kingii Sars, 1888, p. 68. Scapholeberis kingi Sars in Henry, 1919, p. 465; Henry, 1922, p. 29, P1. 4: Fig. 3; Australia.

\section{Type material. Lost.}

Material studied here. See Supplemental Table 2.

Redescription. Parthenogenetic female (Figs. 4A-E, 5, 6 and 7A-E). In lateral view

body relatively elongated, dorsal margin regularly arched, ventral margin almost straight, maximum height at body midpoint (body height/length ratio about 0.6 for adults and 0.5 for juveniles) (Figs. 4A and 7A). In dorsal or ventral view body ovoid, moderately compressed from sides (Fig. 4B). In anterior view body moderately compressed, dorsal keel absent. Posterodorsal angle obtuse, posteroventral angle almost straight, with a long spine (mucro) (Figs. 4A, 5D-E and 7A-C). A row of numerous small setules on inner face of posterior margin of valve (Figs. 
275 5D-E, 7B-C). Ventral margin covered by setae of different size (Figs. 5A-D). Anterovenral 276 angle of valve broadly rounded, its ventral portion with a small protuberance (Fig. 7B). Valves

277 with well-developed sculpture of polygonal reticulation.

$278 \quad$ Head large for a daphniid (Figs. 4A and 7A). In lateral view head elongated, with a 279 prominent rostrum, its distal portion roundish (Figs. 4A and 7A). In dorsal view head elongated, 280 head shield with low lateral projections (fornices) covering bases of antennae II, a sclerotized 281 ridge departs from the insertion of antenna II and extends to the side of head (Fig. 4B). In 282 anterior view head slightly compressed from lateral sides (Figs. 4C and 7D). In ventral view 283 postero-ventral portion of head forms a three-lobed rostrum, due to a shallow depression in 284 points of antenna I insertion on each side, its middle lobe rounded, with a minute frontal head 285 pore (Figs. 4C and 7D-E). In anterior view, distance between the center of ocellus and eye 286 slightly greater (almost twice) than distance from the center of ocellus to the tip of rostrum (Fig. 287 4C). Dorsal head pores absent. Labrum large, distal labral plate with bunches of long setules, in 288 ventral view labrum triangular, with lateral projections (Fig. 4D, 7D). Valve with straight ventral margin (Figs. 4A, 5D and 7A-B). Adhesive ventral rim of 290 valves modified into "sucker-plate" (in terms of Dumont \& Pensaert, 1983), no setae along most 291 part of the sucker length except few rarely located setae at anteriormost portion and several 292 sparsely located setae at posterior portion near mucro (Figs. 5A-C). Inner surface of posterior 293 margin with a broad "hyaline membrane" (in terms of Dumont \& Pensaert, 1983) extending the 294 posterior rim and a "denticulated membrane" (in terms of Dumont \& Pensaert, 1983) consisting 295 of row of short setules along the posterior rim (Figs. 5D-E, 7B-C).

296 Thorax relatively long for daphniids, abdomen short (Fig. 4A). 
Postabdomen almost rectangular, postabdomen length/height ratio about 3 (Figs. 5F-G).

298 Ventral margin almost straight. Preanal margin two times longer than anal margin. Anal and

299 postanal margins almost equal in length. Basis of claws slightly inflated, bordered from distal

300 margin by a clear incision (Figs. 5G-I). Postanal portion of postabdomen armed with long, thin

301 solitary teeth and bunches of fine setules (Figs. 5G-H). Bunches of fine setules also on anal

302 margin and lateral surface of postabdomen. Postabdominal claw long (almost as long as anal

303 margin), slightly curved (Figs. 5H-I). Its external side armed by three rows of small denticles,

304 decreasing in size distally. Denticles in middle portion of claw are stronger and located more

305 sparsely as compared to other denticles. Basal spine absent (Figs. 5H-I).

306 Antenna I jointed to the head surface, relatively short, antennular body with aesthetascs

307 exceeds tip of rostrum in length (Figs. 5J-K, 7D-E). Antennular sensory seta slender, arising

308 subdistally, almost equal in length to antennular body. Nine aesthetascs unequal in size (Figs.

$3095 \mathrm{~J}-\mathrm{K}, 7 \mathrm{E})$. All aesthetasc tips projecting beyond tip of rostrum.

310 Antenna II relatively long (Figs. 4A, 5L-M, 7A). Antennal formula for setae: 0-0-1-3/1-

311 1-3. Antennal formula for spines: 0-1-0-1/0-0-1. Coxal part folded, with two sensory setae. Basal

312 segment elongated, covered by concentric rows of fine setules with a very thin spine between

313 antenna II exopod and endopod branches on outer surface and a short bisegmented seta on outer

314 surface (Figs. 5L-M). Branches relatively elongated, all segments cylindrical, covered by

315 concentric rows of fine setules and tiny denticles around their distal margins. Apical setae typical

316 for daphniids (as long as antennal branches), setulated asymmetrically. Lateral setae arising from

317 basal and middle endopod segment long (reach tips of apical setae) (Fig. 5L). Lateral seta arising

318 from third exopod segment thin and relatively short (reaches the middle of apical setae). Spine

319 on the second exopod segment short and thin. Spines on apical segments of endopod and exopod 
320 branches very small and short, subequal in size to concentric apical denticles, arising from distal

321 portions of apical segments.

322 Thoracic limbs: five pairs (Figs. 6A-E).

323 Limb I with ovoid epipodite (Fig. 6A). Accessory setae long, armed by long setules.

324 Outer distal lobe with two setae unequal in size. Distal segment of the longest seta unilaterally

325 armed by short setules; proximal portion of this seta bears especially long setules. Shorter seta of

326 outer distal lobe bilaterally armed by short setules. Inner distal lobe (endite 5) with three setae

327 unequal in size and shape (Fig. 5A: 1, 1', 1"). Two setae bisegmented, with elongated distal

328 portions. A single seta 1 brush-shaped (in terms of Dumont \& Pensaert, 1983), its distal end

329 abrupt, bearing long thickened setules. Endite 4 with a short anterior seta 2 and two posterior

330 setae (Fig. 6A: a-b). The ratio between seta 1' and seta 2 is almost 2.5 (i.e. seta 2 is relatively

331 short as compared to $S$. cf. intermedius from Africa, see below). Endite 3 with a short and thin

332 anterior seta 3 and two posterior setae (Fig. 6A: c-d). Endite 2 with a short anterior seta 4 and

333 four posterior setae (Fig. 6A: e-h). Two ejector hooks subequal in size.

334 Limb II large (Fig. 6B). Limb distal portion (exopodite) as large ovoid setulated lobe with

335 two soft setae unequal in size. Four endites fused (e5-e2), bearing in toto six setae. Distal

336 segments of anterior setae a-d covered by short denticles. Two posterior setae (Fig. 6B: a, d)

337 bear long setules. Gnathobase (endite 5) with two rows of setae: four anterior setae (Fig. 6B: 1-

338 4, among them seta 1 as a small elongated sensillum) and six posterior setae of gnathobasic

339 "filter plate".

340 Limb III with a large ovoid epipodite (Fig. 6C) and a flat round exopodite bearing four

341 distal setae (Fig. 6C: 1-4), (among them seta 2 the longest) and two lateral setae (Fig. 6C: 5-6)

342 unequal in length. Setae $3-5$ covered by long setules. Setae $1-2$ featured by long setules in their 
343 proximal portions and bearing shorter stiff setules on their distal segments. Inner distal portion of

344 limb with four endites: endite 5 with a single, short anterior seta (1) and a posterior seta (a);

345 endite 4 with a single anterior seta (2) and a single posterior (b) seta; endite 3 with a short

346 anterior seta (3) and two posterior setae (c-d); endite 2 with two anterior seta (4-5?) and four

347 posterior $(\mathrm{e}-\mathrm{h})$ setae. The rest of limb inner-distal portion as a singular large lobe, modified

348 gnathobase, bearing numerous posterior soft setae, each with chitinous insertion within basal

349 portion of distal segment, and a single, relatively long anterior seta (1) in its distal corner (Fig. $3506 \mathrm{C})$.

351 Limb IV with a large ovoid epipodite (Fig. 6D) and wide, flat rounded exopodite with

352 two protruding setulated lobes, four distal (Fig. 6D: 1-4) and two lateral (Fig. 6D: 5-6) setae.

353 Among them seta 4 the longest. Inner-distal portion of this limb with completely fused endites,

354 distally with two setae (Fig. 6D: 1-2) of unclear homology, the most part of limb inner margin is 355 a gnathobase filter plate consisting of numerous posterior setae.

356 Limb V (Fig. 6E) with a setulated preepipodite, large, subovoid epipodite, triangular

357 exopodite supplied with two small, thin distal setae (Fig. 6E: 1-2) unequal in length and a large

358 lateral seta (Fig. 6E: 3). Inner limb portion as an ovoid flat lobe, with setulated inner margin and 359 a single, large seta.

360 Ephippial female (Figs. 4F-H, 7F-L, 8A-G). Body shape in general as in

361 parthenogenetic female. Dorsal portion of valves modified into ephippium. Ephippium dark

362 brown, ovoid, clearly bordered from ventral and lateral portions of valves separating during its

363 casting off (Figs. 4F, 7F-G, I-J). Egg chamber with a single egg, elongated, its sculpture

364 represented by shallow depressions (Figs. 4F-G, 7H, 7L, 8C). Sculpture of the rest of ephippium

365 is represented by small polygons. Lateral keels are well distinguishable from the lateral (Figs. 
$3664 \mathrm{~F}-\mathrm{G}, 7 \mathrm{~F}-\mathrm{G}, \mathrm{I}-\mathrm{J}$ ) and dorsal view (Figs. 8A-B). From the dorsal view, area between two keels

367 strongly elongated, keels not projected laterally out of body dorsal contour (Figs. 8A-B).

368 Preephippial female (Figs. 9A-F). Body shape in general similar to that in

369 parthenogenetic female (Fig. 7A). Lateral keels already visible (Figs. 9A, D-E), but dorsal

370 portion of valves almost weekly chitinized. Ventral and lateral borders between preephippium

371 and the rest of valves not developed (Figs. 9A, D).

372

Male. Despite significant sampling effort, we failed to detect males in the investigated

373

374

375

376

377

378

379

380

381

382

383

384

385

samples. Although males of Scapholeberis have been described by Dumont \& Pensaert (1983), it

is difficult to detect them in nature or in laboratory cultures. In general view, males are similar to

juvenile females and could not be distinguished without dissection. Also, it seems possible, that at least in some Scapholeberis species, ephippial females may appear in the natural populations and under laboratory conditions without males. The same situation is known for some Daphnia O.F. Mueller, 1785 (Kotov, 2013).

Size. Medium-sized species, parthenogenetic female up to $0.55 \mathrm{~mm}$ in length without mucro (and $0.57 \mathrm{~mm}$ with mucro), ephippial female up to $0.57 \mathrm{~mm}$ in length without mucro (and 0.61 with mucro).

Variability. No significant variability was found among the investigated individuals.

Taxonomic notes. King (1853, p. 255-256, plate V, fig. e) found "Daphnia mucronata (Müller)" in "South Creek" and "Paramatta", New South Wales, Australia. In his diagnosis, he mainly reproduced the previous redescription of Scapholeberis mucronata by Baird (1850, p. 99-100) made for European populations, but pointed on two differences of the Australian specimens: (1) "European specimens have the upper part of the head sometimes terminated by a sharp-curved point, and directed upwards. I have not found any such variety here"; (2) "the head 
389 of each of Baird's figures is larger than that of the Australian species". Sars (1888: p. 68) took

390 these differences into his consideration and established new taxon, S. kingii Sars, 1888, referring

391 to the description of King (1853) rather than based on his own original material. It is an

392 acceptable action according to the ICZN (2000). Specimens of this taxon from Australia are

393 absent from the collection of G.O. Sars in the Zoological Museum of the Oslo University,

394 Norway. King's specimens were eligible to be designated as types for S. kingii ICZN (2000), but 395 the specimens were apparently lost.

396 Then Sars (1903, p. 8-10, plate 1, figs 2, 2a, 2b) proposed the name "Scapholeberis

397 Kingi, G.O. Sars, n. sp. "for populations from Sumatra (unknown water bodies in "territories of

398 Deli and Langkat" collected by Mr. Iversen) with the following explanation: "The above-

399 described species is unquestionably identical with the Australian form recorded by King as

400 Daphnia mucronata. It is certainly very nearly allied to the European species, but apparently

401 specifically distinct, differing, as it does, not only in the much smaller size, but also in the shape

402 of the head and in the less sharply angulated anterior part of the valves. The sculpture of the shell

403 is, moreover, much coarser than in the European species". But, Sars' earlier species name " $S$.

404 kingii" of Australia has precedence over the Sumatran species. The Sumatran specimens are

405 present in the Collection of G.O. Sars (GOS F 9540, GOS F 12272, GOS F 12880). However,

406 these specimens are not regarded as types because they were not reported in the original taxon

407 description. According to the drawings of Sars (plate 1, figs 2, 2a, 2b), the specimens from

408 Sumatra belong to the S. kingii group. Presently it is unknown if the populations from Sumatra

409 belong to $S$. kingii s.str., S. smirnovi sp.nov., or another taxon (tropical Asian populations are not

410 revised here). 
412 that $S$. kingi Sars, 1888 was a nomen nudum (and claimed that the species should have been 413 named S. kingi Sars, 1903).

414 Distribution. To date, we can confirm its presence in Australia only, where it is a 415 common taxon (Dumont, 1983; Smirnov, 1995; Shiel \& Dickson, 1995), but we cannot fully

416 exclude the chance that there are several additional taxa within this group.

417 Records of S. kingii from Spain, Sicily and Central Europe have been declared dubious 418 (Alonso 1996; Marrone, Barone \& Naselli-Flores, 2005; Hudec, 2010), but members of the $S$. 419 kingii species group (see below) were found to be common in Northern Africa (Ghaouaci et al., 420 2018; Neretina, 2018). In the Eastern Palearctic, the range of S. cf. kingii extends northwards, up 421 to Japan (Tanaka, 1998a; Tanaka, 1998b), the Korean Peninsula (Kotov, Jeong \& Lee, 2012) and 422 the Russian side of the Amur River (=Heilong Jiang in Chinese) basin (Kotov et al., 2011).

423 Therefore, the $S$. kingii species complex is regarded as a typical "tropicopolitan" taxon with a 424 very wide geographic range in the Eastern Hemisphere.

425

\section{Scapholeberis intermedius Daday, 1898}

Figure 10

428

Scapholeberis mucronata var. intermedia Daday, 1898, p. 59-60, Fig. 29a-b.

431

? Scapholeberis kingi Sars in Gurney, 1907, p. 277-278; Fernando, 1980, p. 97; Michael \& Sharma, 1988, p. 73-74, Fig. 20a-c; Chatterjee et al., 2013, p. 20-21.

432

Type locality. "Sümpfe der Umgebung des Kalawewa-Sees", Sri Lanka (Daday, 1898). 
Type material (studied here). See Supplemental Table 2.

lateral view body elongated and ovoid, dorsal margin regularly arched, ventral margin straight, maximum height at middle of body (body height/length ratio about 0.61 for adults and 0.59 for juveniles) (Figs. 10A-B). Head large with well developed rostrum (Figs. 10A-B). Posterodorsal angle obtuse, posteroventral angle almost straight with long mucro (Figs. 10A-B). Posterior margin generally almost straight or slightly curved. Ventral margin almost straight. Anterovenral angle broadly rounded, its ventral side with small protuberance. portion of rostrum roundish. Compound eye large, ocellus is not recognizable (Figs. 10A-C). Antenna II relatively long, endopod branch slightly longer than exopod (Fig. 10D). Antennal formula identical to previous species.

Ephippial female, male. Completely absent in the type material. mucro (and $0.63 \mathrm{~mm}$ with mucro).

Variability. No significant variability was found in the investigated individuals. now regarded as a junior synonym of Megafenestra aurita Fischer. Unfortunately, type material of $S$. intermedius is represented by permanent slides with parthenogenetic females in the lateral or almost lateral position (Fig. 10). Gamogenetic females and males are completely absent in the type series. Thus, we have no opportunity to compare the morphological features (proportions of 
457 sp.nov. and African S. cf. intermedius (see below). Based on the genetic data, we demonstrated

458 that populations from Ethiopia and the Russian Far East form unique lineages (Figs. 1 and 2).

459 We propose here that $S$. smirnovi sp.nov. is a separate taxon, well delineated from other $S$.

460 kingii-like species (see below). Morphological and genetic investigations of kingii-like

461 populations from the type locality of S. intermedius, Sri Lanka (and South Asia as a whole) will

462 be carried out in future studies. To date we have no suitable material of $S$. kingii with ephippial

463 females from this area.

\section{Scapholeberis cf. intermedius Daday, 1898}

466

Figures 11-15

467

468

? Scapholeberis kingi Sars in Sars, 1916, p. 314-315, Pl. XXXII: 3, 3a, 3f; Brehm, 1937,

p. 489; Gauthier, 1951, p. 48-50, text-figure in p. 49, C-D; Harding, 1961, p. 40; Rey \& Saint-

Pensaert, 1979, p. 265, 267; Day et al., 1999, p. 97, Fig. 4.6.B.

472

473

474

Material studied here. See Supplemental Table 2. middle of body (body height/length ratio about 0.59 for adults, juveniles not studied) (Figs. 11A, 15A). In dorsal and ventral view body ovoid, only moderately compressed from sides. In anterior view body moderately compressed, dorsal keel absent. Head large with well developed rostrum (Figs. 11A-B, 15A-C). Depression between head and rest of body absent, but dorsal contour 
480 may be slightly concave under compound eye and antenna. Posterodorsal and posteroventral

481 angles expressed (Figs. 11A, E, 15A, D). Posterodorsal angle obtuse, posteroventral angle almost

482 straight with long mucro (Figs. 11A, E, 15A, D). Posterior margin generally almost straight or

483 slightly curved. A raw of numerous small setules on inner face of posterior margin of valve

484 (Figs. 11F-G). Ventral margin almost straight, covered by setae of different size (Fig. 11E).

485 Anteroventral angle broadly rounded, its ventral side with small protuberance (Figs. 11A, E,

486 15A, D). Valves with developed sculpture, consisting of polygons (Figs. 11E, 15D-E).

487 Head large for daphniids (Figs. 11A-B, 15A-C). In lateral view head elongated, with a

488 prominent rostrum. Distal portion of rostrum roundish. In anterior view, head elongated and

489 round, slightly compressed from lateral sides (Fig. 11C). Its ventral portion three-lobed with

490 depression for antennulae. A central lobe is rostrum, its tip broadly rounded with small shallow

491 incision. In anterior view, distance between the center of ocellus and eye significantly greater

492 (almost in three times) than distance from the center of ocellus to the tip of rostrum (Fig. 11C).

493 Dorsal head pores absent, frontal head pore was not studied. Labrum large (Fig. 11D). Distal

494 labral plate with bunches of long setules.

495 Valve with straight ventral margin (Figs. 11E). Adhesive ventral rim of valves modified

496 into "sucker-plate". Inner surface of posterior margin with a broad "hyaline membrane" (in terms

497 of Dumont \& Pensaert, 1983) extending the posterior rim and a "denticulated membrane" (in

498 terms of Dumont \& Pensaert, 1983) consisting of row of short setules along the posterior rim

499 (Figs. 11F-G).

500 Postabdomen almost rectangular, slightly narrowing distally; postabdomen length/height

501 ratio about 2.6 (Fig. 11I). Ventral margin straight. Preanal margin three times longer than anal

502 margin. Anal and postanal margins almost equal in length. Basis of claws not inflated (Figs. 11I- 
$503 \mathrm{~J}, 12 \mathrm{~A})$. Postanal portion of postabdomen armed with long and thin denticles and bunches of fine

504 setules. Bunches of fine setules also on anal margin and lateral surface of postabdomen.

505 Postabdominal claw long (almost as long as anal margin), slightly curved (Figs. 11I-J, 12A). Its

506 external side armed by three rows of small denticles, deceasing in size distally. Basal spine

507 absent (Figs. 11I-J, 12A).

508 Antenna I relatively short, antennular body with aesthetascs exceeds tip of rostrum in 509 length (Fig. 11L). Nine aesthetascs unequal in size.

510 Antenna II relatively long (Figs. 11A, 12B-J). Antennal formula for setae: 0-0-1-3/1-1-3.

511 Antennal formula for spines: 0-1-0-1/0-0-1. General structure of antenna II identical to species

512 described above.

$513 \quad$ Thoracic limbs: five pairs.

514 Limb I (Figs. 12K, 13A). Accessory setae very long, prominent. Outer distal lobe with

515 two setae unequal in size. Distal segment of the longest seta unilaterally armed with short

516 setules; proximal portion of this seta bears especially long setules. Shorter seta of outer distal

517 lobe bilaterally covered by short setules. Inner distal lobe (endite 5) with three setae unequal in

518 size and shape (Figs. 12K, 13A: 1, 1', 1"). Endite 4 with a short anterior seta 2 and two posterior

519 setae (Figs. 12K, 13A: a-b). The ratio between seta 1' and seta 2 is almost 1.5 (i.e. seta 2 is

520 relatively long in the comparison of other Scapholeberis species investigated here, see

521 redescription of $S$. kingii above and description of S. smirnovi sp.nov. below). Endite 3 with a

522 short and thin anterior seta 3 and two posterior setae (Figs. 12K, 13A: c-d). Endite 2 with a short

523 anterior seta 4 and four posterior setae (Figs. 12K, 13A: e-h). Two ejector hooks almost similar 524 in size. 

13B-D).

528 four distal setae, (among them seta 2 the longest, Figs. 13E-F) and two lateral setae unequal in portions and bear shorter stiff setules on their distal segments. Inner distal portion of limb (Fig.

531 13E, G) with four endites: endite 5 with a single, short anterior seta (1) and a posterior seta (a); endite 4 with a single anterior seta (2) and a single posterior (b) seta; endite 3 with a short anterior seta (3) and two posterior setae (c-d); endite 2 with two anterior seta (4-5) and four posterior $(\mathrm{e}-\mathrm{h})$ setae. The rest of limb inner-distal portion as a singular large lobe, modified gnathobase, bearing numerous posterior soft setae, each with chitinous insertion within basal portion of distal segment, and a single, relatively long anterior seta (1) in its distal corner. Also, two small sensillae recognizable in this portion. with two protruding setulated lobes, four distal and two lateral setae. Among them seta 4 the

540 longest (Figs. 14A-B). Inner-distal portion of this limb with completely fused endites, distally

541 with two setae of unclear homology, the most part of limb inner margin is a gnathobase filter

542 plate consisting of numerous posterior setae (Fig. 14C). Also, two small sensillae recognizable in 543 this portion. exopodite supplied with two small, thin distal setae (Figs. 14D-E: 1-2) unequal in length and a

546 large lateral seta (Figs. 14D-E: 3). Inner limb portion as an ovoid flat lobe, with setulated inner

547 margin and a single, large seta. A small sensillum recognizable near seta 2. 
Ephippial female, male. Despite significant efforts, we did not find gamogenetic

549 females and males in African localities. Other authors who dealt with the description of African

550 populations also did not observe Scapholeberis ephippial females and males in their materials.

551 Size. Medium-sized species, parthenogenetic female up to $0.70 \mathrm{~mm}$ in length without

552 mucro (and $0.73 \mathrm{~mm}$ with mucro).

553

554

555

556

557

558

559

560

561

562

563

564

565

566

567

568

569

570

Variability. No significant variability was found among the investigated individuals.

Other records in Africa. Distribution of Scapholeberis in Africa remains scarcely

studied. Reliable records of S. kingii populations are known from West Africa (Dumont, 1981;

Egborge, Onwudinjo \& Chigbu, 1994; Chiambeng \& Dumont, 2005), Central Africa (Rey \&

Saint-Jean, 1969), and South Africa (Sars, 1916; Day et al., 1999).

\section{Scapholeberis smirnovi sp. nov.}

Figures 16-20

Scapholeberis kingi Sars in Uéno, 1940, p. 342; Tanaka, 1998a, p. 30-31, Fig. 2A-C;

Tanaka, 1998b: p. 15-16, Fig. 9-10; Tanaka, Ohtaka \& Nishino, 2004, p. 173-174, Fig. 3; Kotov

et al., 2011, p. 403, Table 1; Kotov, Jeong \& Lee, 2012, p. 58, Fig. 5; Jeong, Kotov \& Lee, 2014, p. 219.

? (at least partially) Scapholeberis kingi Sars in Chiang \& Du, 1973, p. 145-146, Fig.

97a-c; in Du Nan-shan, 1973, p. 44, Fig. 13; Xiang et al., 2015, p. 13-14.

Scapholebeis mucronata (O.F. Müller) in Uéno, 1927, p. 281, Fig. 9 (not 9a-9e!);

Scapholeberis rammneri Dumont \& Pensaert in Yoon, 2010, p. 64-66, Fig. 34. 
Publication Zoobank ID. See nomenclatural acta above.

572

Zoobank taxon ID. urn:1sid:zoobank.org:act:62ABBAFB-249D-453A-BB8D-

573

574

575

576

577

578

579

580

581

582

583

584

585

586

587

588

589

590

591 592 developed sculpture of polygonal reticulation.

E59ECB1AB2B0. large advances in the study of freshwater zooplankton. Territory, the Russian Far East. Utinoe, Holotype”. Paratypes. See Supplemental Table 2.

Etymology. The taxon is named after Professor Nikolai N. Smirnov, a renowned Russian zoologist and hydrobiologist, who established the Russian school of cladocerology and made

Type locality. A puddle near Lake Maloe Utinoe (N 43.4127º, E $131.8214^{\circ}$ ), Primorski

Type material. Holotype: an ephippial female, fixed in $96 \%$ ethanol, deposited at the collection of Zoological Museum of Moscow State University, MGU M1-189. The label of holotype is: "Scapholeberis smirnovi sp. nov., 1 ephippial female from puddle near Lake Maloe

Description. Parthenogenetic female (Figs. 16A-F). In lateral view body relatively elongated, dorsal margin regularly arched, ventral margin almost straight, maximum height at body middle (body height/length ratio about 0.6 for adults and 0.5 for juveniles) (Figs. 16A and $16 \mathrm{E}$, correspondingly). In dorsal or ventral view body ovoid, moderately compressed from sides (Fig. 16B). In anterior view body moderately compressed, dorsal keel absent. Posterodorsal angle obtuse, posteroventral angle almost straight, with a long spine (mucro) (Figs. 16A, E and 17A-E). A row of numerous small setules on inner face of posterior margin of valve (Fig. 17E). Ventral margin covered by setae of different size (Figs. 17A-D). Anteroventral angle of valve broadly rounded, its ventral portion with a small protuberance (Fig. 16A, E). Valves with well- 
594 rostrum, its distal portion roundish (Fig. 16A). In dorsal view head elongated, head shield with

595 low lateral projections (fornices) covering bases of antennae II, a sclerotized ridge departs from

596 the insertion of antenna II and extends to the side of head. In anterior view head slightly

597 compressed from lateral sides. In ventral view postero-ventral portion of head forms a three-

598 lobed rostrum, as there is a shallow depression at insertion points of antenna I on each side, its

599 middle lobe rounded, with a minute frontal head pore (Figs. 16C). In anterior view, distance

600 between the center of ocellus and eye significantly greater (almost in five times) than distance

601 from the center of ocellus to the tip of rostrum (Figs. 16F). Dorsal head pores absent. Labrum

602 large (Fig. 16D), similar to other Scapholeberis species.

603 Valve with straight ventral margin (Figs. 16A, 17A). Adhesive ventral rim of valves

604 modified into "sucker-plate" (Figs. 16A-D), details of its structure identical to S. kingii.

605 Thorax relatively long, abdomen short (Fig. 16A).

606 Postabdomen almost rectangular, postabdomen length/height ratio about 2.8 (Figs. 17F-

607 H). Ventral margin almost straight. Preanal margin two times longer than anal margin. Anal and

608 postanal margins almost equal in length. Basis of claws slightly inflated, bordered from distal

609 margin by a clear incision (Figs. 17G-I). Postanal portion of postabdomen armed with long, thin

610 solitary teeth and bunches of fine setules. Bunches of fine setules also on anal margin and lateral

611 surface of postabdomen. Postabdominal claw long (almost as long as anal margin), slightly

612 curved (Figs. 17G-I). Its external side armed by three rows of small denticles, decreasing in size

613 distally. Denticles in middle portion of claw are stronger and distributed more sparsely as

614 compared to other denticles. Basal spine absent (Figs. 17G-I). 
615 Antenna I relatively short, its proportions similar to other Scapholeberis species (Figs.

616 17J-K). Nine aesthetascs unequal in size.

617 Antenna II relatively long (Figs. 16A, 17L-M). Antennal formula for setae: 0-0-1-3/1-1-

618 3. Antennal formula for spines: 0-1-0-1/0-0-1. Fine armature of antenna II similar to S. kingii.

619 Thoracic limbs: five pairs (Figs. 18A-H).

620 Limb I with ovoid epipodite (Figs. 18A-B). Accessory setae long, armed by long setules.

621 Outer distal lobe with two setae unequal in size. Distal segment of the longest seta unilaterally

622 armed by short setules; proximal portion of this seta bears especially long setules. Shorter seta of

623 outer distal lobe bilaterally armed by short setules. Inner distal lobe (endite 5) with three setae

624 unequal in size and shape (Fig. 18A: 1, 1', 1"). Two setae bisegmented, with elongated distal

625 portions. A single seta 1 brush-shaped (in terms of Dumont \& Pensaert, 1983), its distal end

626 abrupt, bearing long thickened setules. Endite 4 with a short anterior seta 2 and two posterior

627 setae (Fig. 18A: a-b). The ratio between seta 1' and seta 2 is almost 2.5 (i.e. seta 2 is relatively

628 short as compared to $S$. cf. intermedius from Africa, and comparable to S. kingii, see above).

629 Endite 3 with a short and thin anterior seta 3 and two posterior setae (Fig. 18A: c-d). Endite 2

630 with a short anterior seta 4 and four posterior setae (Fig. 18A: e-h). Two ejector hooks subequal

631 in size.

632 Limb II large (Fig. 18C-D). Limb distal portion (exopodite) as large ovoid setulated lobe

633 with two soft setae unequal in size. Four fused endites (e5-e2) bear six setae. Distal segments of

634 anterior setae a-d covered by short denticles. Two posterior setae (a and d) bear long setules.

635 Gnathobase (endite 5) with two rows of setae: four anterior setae (Fig. 18C: 1-4, among them

636 seta 1 as a small elongated sensillum) and six posterior setae of gnathobasic "filter plate". 
638 distal setae (Fig. 18E: 1-4), (among them seta 2 the longest) and two lateral setae (Fig. 18E: 5-6)

639 unequal in length. Proportions and armature of all setae similar to S. kingii.

640 Limb IV with a large ovoid epipodite (Fig. 18F-G) and wide, flat rounded exopodite with

641 two protruding setulated lobes, four distal (Fig. 18F: 1-4) and two lateral (Fig. 18F: 5-6) setae.

642 Proportions and armature of all setae similar to S. kingii.

643

Limb V (Fig. 18H) with a subovoid epipodite, triangular exopodite supplied with two

644 small, thin distal setae (Fig. 18H: 1-2) unequal in length and a large lateral seta (Fig. 18H: 3).

645 Inner limb portion as an ovoid flat lobe, with setulated inner margin and a single, large seta.

646 Ephippial female (Figs. 16G-I, 19A-B, D-F, 20A-L). Body shape in general as in

647 parthenogenetic female. Dorsal portion of valves modified into ephippium. Ephippium dark

648 brown, ovoid, clearly bordered from ventral and lateral portions of valves separating during its

649 casting off (Figs. 16G, 19A-B, 20A, D). Egg chamber with a single egg, elongated, its sculpture

650 represented by shallow depressions (Figs. 16G, 20F). Sculpture of the rest of ephippium is

651 represented by small polygons. Lateral keels are well distinguishable from the lateral (Figs. 16G,

652 19A-B, 20A-D) and dorsal view (Figs. 16H, 19-E, 20G, I-L). From the dorsal view, area

653 between two keels strongly rounded, keels strongly projected laterally out of body dorsal contour

654 (Figs. 16H, 19D, 20G).

655

Preephippial female (Figs. 19C). Body shape in general similar to that in

parthenogenetic female. Lateral keels already visible (Figs. 19C), but dorsal portion of valves

657 weakly chitinized. Ventral and lateral borders between preephippium and the rest of valves not

658 developed.

Male. Despite significant efforts, we did not find males in the investigated samples. 
661 South Korea and the Russian Far East surprised cladoceran investigators (Kotov, Jeong \& Lee, 662 2012). However, we now know that the Far Eastern populations belong to a separate taxon, the 663 real distribution of which needs to be accurately evaluated. To date, we had no DNA-available 664 samples of S. cf. kingii from SE Asia, South China and Indian subcontinent where that taxon is 665 common (Michael \& Sharma, 1988; Korovchinsky, 2013; Kotov et al., 2013; Sinev, Gu \& Han, 666 2015). Checking of the status of populations from different regions of the Palaeotropics is the 667 next step in the revision of this group.

668 Our revision confirms again that the Far East of Eurasia, in its temperate portion, is an 669 important source of new taxa, as it was already found previously (Kotov, Ishida \& Taylor, 2009; 670 Kotov et al., 2011).

671 Size. Medium-sized species, parthenogenetic female up to $0.75 \mathrm{~mm}$ in length without 672 mucro (and 0.79 with mucro), ephippial female up to $0.70 \mathrm{~mm}$ in length (without mucro) (and 6730.72 with mucro). Holotype $0.60 \mathrm{~mm}$ in length (without mucro), $0.37 \mathrm{~mm}$ in height.

674 Distribution. This taxon is known from the southern portion of the Far East of Russia, 675 the Korean Peninsula, Japan and an adjacent region of China (Dongbei = Manchuria). It has also 676 been recorded from a single locality in the southernmost portion of European Russia, but such a 677 disjunct population may be due to an anthropogenic introduction. 

species groups of neustonic daphniids exist for both rRNA (Taylor, Connelly \& Kotov, 2020) and protein-coding regions of the mitochondrial genome (the present study). Costa et al. (2007) reported a $1.32 \%$ average divergence within species of Daphnia and a maximum divergence of $20 \%$ in divergence. These unusually high maximum values for Scapholeberis are unlikely to be reduced with further geographic sampling. The COI data showed similar levels of within genus variation for Daphnia (Costa et al. 2007), Scapholeberis and Megafenestra at just over 30\%, while the rRNA genes show greater divergences within neustonic genera (Scapholeberis and Megafenestra) compared to those from other cladoceran genera (Taylor, Connelly \& Kotov, 2020). This outcome is expected for rate increases in COI because the gene is prone to strong purifying selection resulting in substitutional saturation (Pentinsaari, et al. 2016). sequences (Taylor, Connelly \& Kotov, 2020). The major groups in both trees are the same, while the grouping of the deep branches is different. But, as the deep branches for COI have low support, the discrepancies may be due to random error. by four main clades. Our study confirms that the mucronata-group (clade X) is present in non(Jeffery et al. 2011). 
705 previously unknown clade Y in Israel; (3) the grouping of clade I (which is also basal in the 706 rRNA tree) with other clades is not well-supported in the COI tree.

707 The present study has much improved the geographic sampling of the $S$. freyi group

708 compared to our rRNA tree (this is largely due to the inclusion of sequences from previous DNA

709 barcoding projects). It is clear from the present results that $S$. freyi is indeed a diverse clade with

710 many closely related, but geographically differentiated phylogroups in the New World.

711 There is a new genetic clade within the $S$. kingii species group, $S$. cf. intermedius (clade

712 L2) (Figs 1-2) which was not sampled in the rRNA study. Therefore, the S. kingii group is more

713 diverse as it was expected before. In our COI tree, S. armata (clade N) grouped with $S$. cf.

714 microcephala (clade E) (Fig. 2), but they are distant branches on the rRNA tree. The source of

715 the incongruence is unknown but such discrepancies are common with long branches and short

716 internodes (see Omilian \& Taylor, 2001; Bergstren, 2005).

717 Finally, the Megafenestra internal tree structure is different from that in rRNA tree, as the clade

$718 \mathrm{P}$ is sister group of $\mathrm{Q}$ in the $\mathrm{COI}$ tree and $\mathrm{O}-$ in the rRNA tree.

719

720

De-coding of the DNA barcoding results

721

Before our study, 48 COI sequences were deposited to GenBank: De Waard et al. (2006)

722 (1 sequence); Richter, Olesen \& Wheeler (2007) (1); Elías-Gutiérrez et al. (2008) (6); Jeffrey,

723 Elías-Gutiérrez \& Adamowicz (2011) (2); Elías-Gutiérrez \& León-Regagnon (2013) (3);

724 Prosser, Martínez-Arce \& Elías-Gutiérrez. (2013) (2); Yang et al. (2017) (1); Elias-Gutierrez et

725 al. (2018) (14), and 20 sequences as direct submissions, including the iBOL releases. Because

726 the taxonomy of the Scapholeberinae is immature, identifications of the taxa by authors of these

727 data were tentative (Fig. 21), only $30 \%$ of taxa were identified to species group accurately, while 
728 others were misidentified or identified to the genus level. In some publications, species were

729 assigned to numbers: e.g. "sp. 1, sp. 2 and sp. 3" of Jeffrey, Elías-Gutiérrez \& Adamowicz

730 (2011). Subsequently, S. duranguensis was reasonably described from Mexico (Quiroz-Vázquez

$731 \&$ Elías-Gutiérrez, 2009) based on specific COI sequences and morphological differences from

732 other North American taxa, but no suggestions on the diversity within the genus were made. $S$.

733 yahuarcaquensis was described recently from South America (Andrade-Sossa, Buitron-Caicedo

$734 \&$ Elías-Gutiérrez, 2020), it corresponds to our clade J4.

735 Assessments of species diversity based on genetics can be confused by an immature

736 taxonomic scaffold (as in Scapholeberis and Megafenestra). Indeed, before our study, GenBank

737 was a source of misidentification, as $70 \%$ of sequences had incorrect labels. The barcoding data

738 were an illegitimate alternative to real taxonomy based on the species typification and accurate

739 descriptions/identifications (see Kotov \& Gololobova, 2016). Moreover, when there are

740 pervasive rate differences among taxa for mitochondrial DNA, as has been proposed for

741 neustonic daphniids (Taylor, Connelly \& Kotov, 2020), mitochondrial DNA approaches may

742 yield very different diversity estimates from morphological or nuclear genomic evidence.

743 Our recent decoding of the data from GenBank led to several interesting conclusions. The

744 owners of sequences had no chance to make them because the barcoding data were not well-

745 integrated with taxonomy. Note that the following our conclusions are mainly based on the

746 analysis of the GenBank sequences rather than our original data: (1) S. freyi is not a subspecies

747 of S. armata, and even not single monotypic species, but a monophyletic group of closely related

748 genetic lineages (potential biological species) with a clear latitudinal differentiation in the

749 Americas. Our previous hypothesis that S. freyi is a part of S. rammneri group (Taylor, Connelly

$750 \&$ Kotov, 2020) was wrong. Note that to date only $S$. freyi s. lat. is genetically detected in tropical 
751 South and Central America. This conclusion agrees with opinions based on morphological data

752 (Elmoor-Loureiro, 2000; Elías-Gutiérrez, Kotov \& Garfias-Espejo, 2006). In contrast, S. freyi

753 has not been detected in the western half of the Nearctic. S. yahuarcaquensis was also found in

754 Europe - this population is most probably the result of human-mediated introduction (see also

755 Taylor, Connelly \& Kotov, 2020). The European population was used for a genomic study and

756 identified as “S. mucronata group” (Cornetti et al., 2019).

757 (2) S. duranguensis is a member of a large group, namely the $S$. freyi species group. It is

758 not micro-endemic of a single locality in Durango State, but also present in the mountains of

759 Aguascalientes State.

760 (3) Members of the S. mucronata group (namely clade X) are present in non-Beringian

761 North America, but probably only in its northernmost (Arctic) portion.

762 (4) A new lineage (most probably, a separate biological species) of the rammneri group is

763 present in Israel.

764

(5) In contrast to our previous opinion (Taylor, Connelly \& Kotov, 2020) representatives

765 of the American clade $\mathrm{H}$ of the rammneri group are found in the Beringian zone (although they

766 probably do not extend beyond the boreal zone in Alaska).

767

The information from "genetic barcoding" allows us to improve the biogeography of

768

neustonic daphniids, but only after integrating this information with morphological and other

769

genetic data (Schlick-Steiner et al., 2010).

770

771

\section{Taxonomy}

772

There are two species within the genus Megafenestra (Dumont \& Pensaert, 1983): M.

773 aurita (Fischer, 1849) and M. nasuta (Birge, 1879), and eleven valid species within the genus 
774 Scapholeberis: (1) S. mucronata (O.F. Müller, 1776); (2) S. spinifera (Nicolet, 1849); (3) S.

775 armata Herrick, 1882; (4) S. kingii Sars, 1888; (5) S. microcephala Sars, 1890; (6) S. erinaceus

776 Daday, 1903; (7) S. rammneri Dumont \& Pensaert, 1983; (8) S. freyi Dumont \& Pensaert, 1983;

777 (9) S. duranguensis Quiroz-Vázquez \& Elías-Gutiérrez, 2009; (10) S. yahuarcaquensis

778 Andrade-Sossa, Buitron-Caicedo \& Elías-Gutiérrez, 2020; (10) S. smirnovi sp.nov.

779 But at least four "species" from this list (S. kingi, S. microcephala, S. mucronata, S.

780 rammneri) could be considered as taxa requiring special attention to their taxonomy due to their

781 very broad ranges both in the Eastern and Western Hemispheres. Such taxa need careful

782 taxonomic revisions according to the logic of "non-cosmopolitanism" and "continental

783 endemism" approaches (Frey, 1982; Frey, 1987) widely accepted in the cladoceran taxonomy

784 and biogeography.

785 After two subsequent revisions (Taylor, Connelly \& Kotov, 2020; this study) we know

786 that the diversity of both genera has been strongly underestimated. The subfamily includes at

787 least 23-24 distinct lineages (note that rare S. erinaceus was not studied either here or by Taylor,

788 Connelly \& Kotov (2020). In contrast to many other cladoceran groups, we can confidently say

789 that the phylogeny and taxonomy of Scapholeberinae is now relatively well-done. Main species

790 groups correspond well to those separated based on the morphological analysis. But it is very

791 obvious that further studies are necessary to find morphological differences between revealed

792 taxa and formulate diagnoses of the taxa which needs to be formally described (as Megafenestra

793 cf. nasuta clade P, Scapholeberis cf. microcephala clade E., S. cf. rammneri clades I, and

794 possibly other un-named clades). Therefore the revision of the taxonomy only starts with this

795 contribution. After all, from the lineages discovered up to now (and there are surely more to be

796 found), most remain unnamed and phenotypically not characterised. 
To date we do not know if these taxa are morphologically different from congeneric taxa.

798 But, in this context, it is very premature to discuss a "lacking of resolution" of morphology and

799 the "limitations inherent in morphology-based identification system" (Hebert et al., 2003: $p$.

800313 ), as nobody tried to find such differences. Such search is a task for future.

801 We can immediately recommend the main direction of such studies: gamogenetic

802 specimens must be analyzed for diagnostic characters first, as we did for the $S$. kingii species

803 group. We can assume, following ideas of Goulden (1966), that differences in the ephippial

804 morphology could provide a mechanism of reproductive isolation, as such differences could be

805 used by male during the copulation to recognize correct mate. Lateral keels on the ephippium,

806 characteristic of several, if not all, taxa of Scapholeberis, are analogous to the keels in

807 Bosminidae (Kotov, 2013). Kerfoot \& Peterson (1980) proposed that the lateral keels and special

808 texture on the ephippium of Bosmina also contribute to pre-zygotic reproductive isolation. We

809 believe that differences between Scapholeberis ephippial females could also contribute to

810 reproductive isolation among congeneric species. Moreover, the situation with Scapholeberis

811 kingii and S. smirnovi sp.nov., when parthenogenetic females are morphologically

812 indistinguishable, but gamogenetic specimens have morphological differences, are usual among

813 the cladocerans (Belyaeva \& Taylor, 2009; Popova et al., 2016; Smirnov \& Kotov, 2018). Such

814 phenomena need further study to be accurately explained, but it is obvious that the

815 morphological evolution in parthenogenetic and gamogenetic specimens follow somewhat

816 different pathways. And the oft-reported morphological stasis in cladocerans (Sacherová \&

817 Hebert, 2003; Smirnov \& Kotov, 2018) is more characteristic of parthenogenetic females (the

818 sexual stages appear to evolve more rapidly in morphology).

819 


\section{Acknowledgements}

821

822 Many thanks to E.I. Bekker, J.F. Cart, A. V. Chabovsky, S.E. Cherenkov, S.J. Connelly, 823 Y.R. Galimov, S. Ishida, P.D. Karabanov, Y. Kobayashi, T.P. Korobkova, L.E. Savinetskaya, 824 A.B. Savinetsky and D.V. Vasilenko for samples with the Scapholeberinae, M. Ballinger, K.S. 825 Costanzo, N.M., Korovchinsky and A. Medeiros for assistance in sampling trips.

826 We are deeply grateful to Sergei I. Metelev and Alexey N. Nekrasov for technical 827 assistance during SEM investigations. SEM works are carried out at the Joint Usage Center 828 "Instrumental Methods in Ecology" at A.N. Severtsov Institute of Ecol. Evol. of Russian 829 Academy of Sciences. 
831

832

833

834 of divergence: a phylogenetic appraisal of intercontinental allopatric speciation in a passively

835 dispersed freshwater zooplankton genus. Molecular Phylogenetics and Evolution 50: 423-436.

836 DOI 10.1016/j.ympev.2008.11.026

837

838

839

840

841

842

843

844

845

846

847

848

849

850

851

852

853

\section{References}

Adamowicz SJ, Petrusek A, Colbourne JK, Hebert PDN, Witt JDS. 2009. The scale

Alexeev VR, Tsalolikhin SYM. 2010. Identification guide of zooplankton and

zoobenthos in freshwaters of European Russia. Vol. 1. Zooplankton. Moscow: KMK.

Andrade-Sossa C, Buitron-Caicedo L, Elías-Gutiérrez M. 2020. A new species

of Scapholeberis Schoedler, 1858 (Anomopoda: Daphniidae: Scapholeberinae) from the

Colombian Amazon basin highlighted by DNA barcodes and morphology. PeerJ 8: e9989.

DOI 10.7717/peerj.9989Baird W. 1850. The natural history of the British Entomostraca.

London: The Ray Society.

Bekker EI, Karabanov DP, Galimov YR, Kotov AA. 2016. DNA barcoding reveals

high cryptic diversity in the North Eurasian Moina Species (Crustacea: Cladocera). PLoS ONE 11(8): e0161737.

DOI 10.1371/journal.pone.0161737

Belyaeva M, Taylor DJ. 2009. Cryptic species within the Chydorus sphaericus species complex (Crustacea: Cladocera) revealed by molecular markers and sexual stage morphology. Molecular Phylogenetics and Evolution 50: 534-546.

DOI 10.1016/j.ympev.2008.11.007

Benson DA, Cavanaugh M, Clark K, Karsch-Mizrachi I, Lipman DJ, Ostell J,

Sayers EW. 2012. GenBank. Nucleic acids research 41(D1): D36-D42. 
854

855 $856488-502$.

857

858

860

861

862

863

864

865

866

867

868

869

870

871

872

873

874

875

876

DOI 10.1093/nar/gks1195

Brehm V. 1938. Cladoceren and Ostracoden (d'Angola). Archiv für Hydrobiologie 32:

\section{Chatterjee T, Kotov AA, Van Damme K, Chandrasekhar SVA, Padhye S. 2013. An}

annotated checklist of the Cladocera (Crustacea: Branchiopoda) from India. Zootaxa 3667: 1-89.

$$
\text { DOI 10.11646/zootaxa.3667.1.1 }
$$

Chiambeng GY, Dumont HJ. 2005. The Branchiopoda (Crustacea: Anomopoda,

Ctenopoda and Cyclestherida) of the rain forests of Cameroon, West Africa: low abundances,

few endemics and a boreal-tropical disjunction. Journal of Biogeography 32: 1611-1620.

DOI 10.1111/j.1365-2699.2005.01280.x

Cornetti L, Fields PD, Van Damme K, Ebert D. 2019. A fossil-calibrated

phylogenomic analysis of Daphnia and the Daphniidae. Molecular Phylogenetics and Evolution 137:250-262.

DOI 10.1016/j.ympev.2019.05.018

Day JA, Stewart BA, de Moor IJ, Louw A.E. 1999. Guides to the Freshwater

Invertebrates of Southern Africa: Crustacea I: Notostraca, Anostraca, Conchostraca and

Cladocera. Water Research Commission Report No. TT 121/00, Pretoria: 1-126.

DeWaard JR, Sacherova V, Cristescu MEA, Remigio EA, Crease TJ, Hebert PDN.

2006. Probing the relationships of the branchiopod crustaceans. Molecular Phylogenetics and

Evolution 39 (2):491-502.

DOI 10.1016/j.ympev.2005.11.003

Dumont HJ. 1981. Cladocera and free-living Copepoda from the Fouta Djalon and adjacent mountain ares in West Africa. Hydrobiologia 85(2): 97-116. 
DOI 10.1007/BF00006620

878

Dumont HJ. 1983. Genus Simocephalus Schoedler, 1858. Genus Scapholeberis

879 Schoedler, 1858. In: Smirnov NN, Timms BV, eds. A revision of the Australian Cladocera 880 (Crustacea). Records of the Australian Museum Suppl. 1: 97-106.

881 Dumont HJ, Laureys P, Pensaert J. 1979. Anostraca, Conchostraca, Cladocera and 882 Copepoda from Tunisia. Hydrobiologia 66(3): 259-274.

883 Dumont HJ, Pensaert J. 1983. A revision of the Scapholeberinae (Crustacea:

884 Cladocera). Hydrobiologia 100: 3-45.

885 DOI $10.1007 / \mathrm{BF} 00027420$

886 Dumont HJ, \& Van de Velde I. 1977. Cladocères et Conchostracéc récoltes par le 887 professeur Th. Monod dans la moyenne vallée du Niger en décembre 1972 et janvier 1973. Bull. 888 Inst. fondam. Afr. Noire (sér. A) 39 (1): 75-93.

889 Du Nan-shan. 1973. Cladocera of China. Peking: Science Press, Academia Sinica. 890 Dupérré N. 2020. Old and new challenges in taxonomy: what are taxonomists up 891 against? Megataxa 1(1): 59-62.

$892 \quad$ DOI $10.11646 /$ megataxa.1.1.12

893 Egborge ABM, Onwudinjo CC, Chigbu PC. 1994. Cladocera of coastal rivers of 894 western Nigeria. Hydrobiologia 272(1/2): 39-46.

895 DOI 10.1007/BF00006511

896 Elías-Gutiérrez M, Kotov AA, Garfias-Espejo T. 2006. Cladocera (Crustacea:

897 Ctenopoda, Anomopoda) from southern Mexico, Belize and northern Guatemala, with some 898 biogeographical notes. Zootaxa 1119: 1-27.

$899 \quad$ DOI 10.11646/zootaxa.1119.1.1 
PDN. 2008. DNA barcodes for Cladocera and Copepoda from Mexico and Guatemala,

902 highlights and new discoveries. Zootaxa 1839: 1-42.

903

DOI 10.11646/zootaxa.1839.1.1

904

Elías-Gutiérrez M, León-Regagnon V. 2013. DNA barcoding in Mexico: an

905

introduction. Molecular Ecology Resources 13(6): 1093-1096.

906

DOI $10.1111 / 1755-0998.12149$

907

Elías-Gutiérrez M, Valdez-Moreno M, Topan J, Young MR, Cohuo-Colli JA. 2018.

908

Improved protocols to accelerate the assembly of DNA barcode reference libraries for freshwater zooplankton. Ecology and evolution 8(5): 3002-3018.

910

DOI 10.1002/ece3.3742

911

EImoor-Loureiro LMA. 2000. Ocorrência de Scapholeberis armata freyi Dumont \&

912 Pensaert (Crustacea, Anomopoda, Daphniidae) no estado de São Paulo, Brasil. Revista Brasileira 913 de Zoologia 17(1): 301-302.

914 DOI 10.1590/S0101-81752000000100026

915

Fernando CH. 1980. The freshwater zooplankton of Sri Lanka, with a discussion of tropical freshwater zooplankton composition. Internationale Revue der gesamten Hydrobiologie

917 und Hydrographie 65(1): 85-125.

918

DOI 10.1002/iroh.19800650105

919

Frey DG. 1982. Questions concerning cosmopolitanism in Cladocera. Archiv für

920

Hydrobiologie 93: 484-502.

921

Frey DG. 1987. The taxonomy and biogeography of the Cladocera. Hydrobiologia 145:

922

5-17. 
923

924

925

926

927

928

929

930

931

932

933

934

935

936

937

938

939

940

941

942

943

944

DOI 10.1007/978-94-009-4039-0_2

Ghaouaci S, Amarouayache M, Sinev AY, Korovchinsky NM, Kotov AA. 2018. An

annotated checklist of the Algerian Cladocera (Crustacea: Branchiopoda). Zootaxa 4377 (3):

412-430.

DOI 10.11646/zootaxa.4377.3.5

Goulden CE. 1966. Co-occurence of moinid Cladocera and possible isolating

mechanisms. Verhandlungen der Internationalen Vereinigung für Theoretische und Angewandte

Limnologie 16(3): 1699-1672.

DOI $10.1080 / 03680770.1965 .11899491$

Gurney R. 1907. On some freshwater Entomostraca in the collection of the Indian

Museum, Calcutta. Journal and Proceedings of the Asiatic Society of Bengal, New Series 2(7): $273-281$.

Hebert PDN, Cywinska A, Ball SL, De Waard JR. 2003. Biological identifications

through DNA barcodes. Proceedings of the Royal Society, Series B 270: 313-321.

DOI 10.1098/rspb.2002.2218

Henry M. 1919. On some Australian Cladocera. Journal and Proceedings of the Royal

Society of New South Wales 52: 463-485.

Henry M. 1922. A monograph of the freshwater Entomostraca of New South Wales. Part

I. Cladocera. Proceedings of the Linnean Society of New South Wales 47(1): 186: 26-52.

Hudec I. 1983. Redescription of Scapholeberis echinulata Sars 1903 (Crustacea:

Cladocera). Hydrobiologia 107: 63-69.

DOI $10.1007 / \mathrm{BF} 00126705$ 
code of zoological nomenclature. Fourth edition. London: The Natural History Museum.

Phylogeographical Affinities of the Branchiopoda (Crustacea) of Churchill, Manitoba, Canada.

DOI 10.1371/journal.pone.0018364

951

Jeong HG, Kotov AA, Lee W. 2014. Checklist of the freshwater Cladocera (Crustacea:

Branchiopoda) of South Korea. Proceedings of the Biological Society of Washington 127(1):

$953216-228$.

954

DOI 10.2988/0006-324X-127.1.216

955

Kerfoot WC, Peterson C. 1980. Predatory copepods and Bosmina: replacement cycles

and further influences of predation upon prey reproduction. Ecology 61: 417-431.

957

DOI $10.2307 / 1935198$

958

King RL. 1853. On Australian Entomostraca - in continuation. Papers and proceedings

of the Royal Society of Tasmania 2: 253-263.

960 Korovchinsky NM. 2013. Cladocera (Crustacea: Branchiopoda) of South East Asia:

961 history of exploration, taxon richness and notes on zoogeography. Journal of Limnology 72(s2):

$962109-124$.

963

DOI 10.4081/jlimnol.2013.s2.e7

964

Kotov AA. 2013. Morphology and phylogeny of the Anomopoda (Crustacea: Cladocera).

965

Moscow: KMK Press.

966 Kotov AA, Gololobova MA. 2016. Traditional taxonomy - quo vadis? Integrative

967 Zoology 11: 500-505. 
DOI $10.1111 / 1749-4877.12215$

969

Kotov AA, Ishida S, Taylor DJ. 2009. Revision of the genus Bosmina Baird, 1845

970 (Cladocera: Bosminidae), based on evidence from male morphological characters and molecular 971 phylogenies. Zoological Journal of the Linnean Society 156 (1): 1-56.

972

973

974

east of the Korean Peninsula, with twenty new records for Korea. Zootaxa 3368: 50-90.

975

DOI 10.11646/zootaxa.3368.1.4

976

Kotov, AA, Sinev AY, Glagolev SM, Smirnov NN. 2010. Water fleas (Cladocera). In:

Alexeev VR \& Tsalolokhin SY, eds. Key book for zooplankton and zoobenthos of fresh waters of

European Russia. Moscow: KMK, 151-276.

979

Kotov AA, Korovchinsky NM, Sinev AY, Smirnov NN. 2011. Cladocera (Crustacea,

Branchiopoda) of the Zeya basin (Amurskaya Area, Russian Federation). 3. Systematic-faunistic

981

982

983

984

985

986

987

988

989

990 and zoogeographic analysis. Zoologichesky Zhurnal 90: 402-411.

Kotov AA, Van Damme K, Bekker EI, Siboualipha S, Silva-Briano M, Adabache

Ortiz A, Galván de la Rosa R, Sanoamuang L. 2013. Cladocera (Crustacea: Branchiopoda) of

Vientiane province and municipality, Laos. Journal of Limnology 72(s2): 81-108.

DOI 10.4081/jlimnol.2013.s2.e6

Laforsch C, Tollrian R. 2000. A new preparation technique of daphnids for Scanning

Electron Microscopy using hexamethyldisilazane. Archiv fuer Hydrobiologie 149: 587-596.

Lemoine F, Entfellner JBD, Wilkinson E, Correia D, Felipe MD, De Oliveira T,

Gascuel O. 2018. Renewing Felsenstein's phylogenetic bootstrap in the era of big data. Nature 556: 452-456. 
991

992

993

994

995

996

997

998

999

1000

1001

1002

1003

1004

1005

1006

1007

1008

1009

1010

1011

1012

1013

DOI 10.1038/s41586-018-0043-0

Marrone F, Barone R, Naselli-Flores L. 2005. Cladocera (Branchiopoda: Anomopoda, Ctenopoda, and Onychopoda) from Sicilian inland waters: An updated inventory. Crustaceana 78: $1025-1039$.

Michael RG, Sharma BK. 1988. Fauna of India and ajancent countries. Indian

Cladocera (Crustacea: Branchiopoda: Cladocera). Calcutta: Zool. Surv. India.

Neretina AN. 2018. Fauna of the Cladocera (Crustacea: Cladocera) of Ethiopia.

Unpublished D. Phil. Thesis, A.N. Severtsov Institute of Ecology and Evolution.

Neretina AN, Sinev AY. 2016. A revision of the genus Leberis Smirnov, 1989

(Cladocera: Chydoridae) in the Old World and Australia. Zootaxa 4079(5): 501-533.

DOI 10.11646/zootaxa.4079.5.1

Popova EV, Petrusek A, Koř́ńnek V, Mergeay J, Bekker EI, Karabanov DP,

Galimov YR, Neretina TV, Taylor DJ, Kotov AA. 2016. Revision of the Old World Daphnia

(Ctenodaphnia) similis group (Cladocera: Daphniidae). Zootaxa 4161(1): 1-40.

DOI 10.11646/zootaxa.4161.1.1.

Prosser S, Martínez-Arce A, Elías-Gutiérrez M. 2013. A new set of primers for COI amplification from freshwater microcrustaceans. Molecular ecology resources 13(6): 11511155.

DOI 10.1111/1755-0998.12132.

Omilian AR, Taylor DJ. 2001. Rate acceleration and long-branch attraction in a

conserved gene of cryptic daphniid (Crustacea) species. Molecular Biology and Evolution

18(12): 2201-2212.

DOI 10.1093/oxfordjournals.molbev.a003767 
1015 widely-adopted taxonomic marker (COI) across the animal tree of life. Scientific

1016 Reports 6: 35275.

1017 DOI $10.1038 /$ srep35275

1018 Quiroz-Vázquez P, Elías-Gutiérrez M. 2009. A new cryptic species of the freshwater

1019 cladoceran genus Scapholeberis Schoedler, 1858 (Cladocera: Anomopoda) from the Semidesert

1020 Northern Mexico, highlighted by DNA barcoding. Zootaxa 2236: 50-64.

$1021 \quad$ DOI $10.11646 /$ zootaxa.2236.1.4

1022 Rey J, Saint-Jean L. 1969. Les Cladocères (Crustacés, Branchiopodes) du Tchad

1023 (Deuxième note). Cahiers ORSTOM, série Serie Hydrobiologie 3: 21-42.

1024 Richter S, Olesen J, Wheeler WC. 2007. Phylogeny of Branchiopoda (Crustacea) based 1025 on a combined analysis of morphological data and six molecular loci. Cladistics 23(4): 301-336.

1026 DOI 10.1111/j.1096-0031.2007.00148.x

1027 Ronquist F, Teslenko M, van der Mark P, Ayres DL, Darling A, Höhna S, Larget

1028 B, Liu L, Suchard MA, Huelsenbeck JP. 2012. MrBayes 3.2: Efficient Bayesian phylogenetic

1029 inference and model choice across a large model space. Systematic biology 61(3): 539-542.

$1030 \quad$ DOI $10.1093 /$ sysbio/sys029

1031 Sacherová V, Hebert PDN. 2003. The evolutionary history of the Chydoridae

1032 (Crustacea: Cladocera). Biological Journal of the Linnean Society 79: 629-643.

1033 DOI $10.1046 /$ j.1095-8312.2003.00216.x

1034 Sars GO. 1903. Fresh-water Entomostraca from China and Sumatra. Archiv for

1035 Mathematik og Naturvidenskab 25(8): 1-44. 
Sars GO. 1916. The fresh-water Entomostraca of the Cape Province (Union of South

1037

1038

1039

1040

1041

1042

1043

1044

1045

1046

1047

1048

1049

1050

1051

1052

1053

1054

1055

1056

1057

Africa). Part 1: Cladocera. Annals of the South African Museum 15: 303-351.

Schlick-Steiner BC, Steiner FM, Seifert B, Stauffer C, Christian E, Crozier RH.

2010. Integrative taxonomy: a multisource approach to exploring biodiversity. Annual Review of

Entomology 55: 421-438.

DOI 10.1146/annurev-ento-112408-085432

Shiel RJ, Dickson JA. 1995. Cladocera recorded from Australia. Transactions of the Royal Society of South Australia 119(1): 29-40.

Sinev AY, Gu Y, Han BP. 2015. Cladocera of Hainan Island, China. Zootaxa 4006 (3): $569-585$.

DOI 10.11646/zootaxa.4006.3.9

Sinev AY, Karabanov DP, Kotov AA, 2020. A new North Eurasian species of the Alona affinis complex (Cladocera: Chydoridae). Zootaxa 4767: 115-137.

DOI 10.11646/zootaxa.4767.1.5

Smirnov NN. 1992. The Macrothricidae of the world. Guides to the identification of the microivertebrates of the Continental Waters of the world. The Hague: SPB Academic Publishing.

Smirnov NN. 1995. Check-list of the Australian Cladocera (Crustacea). Arthropoda Selecta 4(1): 3-6.

Smirnov NN. 1996. Cladocera: the Chydorinae and Sayciinae (Chydoridae) of the world. Guides to the identification of the microivertebrates of the Continental Waters of the world. Amsterdam: SPB Academic Publishing. 
Smirnov NN, Kotov AA. 2018. On morphological radiation of Cladocera (Crustacea).

1059

1060

1061

1062

1063

1064

1065

1066

1067

1068

1069

1070

1071

1072

1073

1074

1075

1076

1077

1078

1079

1080

Invertebrate Zoology 15(3): 231-248.

Tanaka S. 1998a. Microcrustaceans (Cladocera and Copepoda) of Ryushou-ike Pond located in the central part of the Hida Mountain Range. Bull. Toyama Biol. Soc. 37: 29-34.

Tanaka S. 1998b. Notes on the Cladocera of Japan - 6. Family Daphniidae Straus, 1820 -

3. Genus Ceriodaphnia and genus Scapholeberis. Memoirs of the Faculty of Education Toyama University, Series B. Natural Sciences 52: 9-18.

Tanaka S, Ohtaka A, Nishino M. 2004. Cladoceran fauna in littoral zones and Naikos (attached lakes or lagoons) of Lake Biwa, central Japan. Japanese Journal of Limnology 65: $167-179$.

Taylor DJ, Connelly SJ, Kotov AA. 2020. The Intercontinental phylogeography of neustonic daphniids. Scientific Reports 10(1): 1-12.

DOI $10.1038 / \mathrm{s} 41598-020-58743-8$

Thielsch A, Knell A, Mohammadyari A, Petrusek A, Schwenk K. 2017. Divergent clades or cryptic species? Mito-nuclear discordance in a Daphnia species complex. BMC Evolutionary Biology 17(1): 227.

DOI 10.1186/s12862-017-1070-4

Turko P, Wolinska J, Tellenbach C, Dziuba MK, Monchamp ME, Spaak P. 2019.

Using DNA from formaldehyde-preserved Daphnia to reconstruct past populations.

Hydrobiologia 841(1): 153-161.

DOI 10.1007/s10750-019-04015-0

Uéno M. 1927. The freshwater Branchiopoda of Japan I. Memoirs of the College of Science, Kyoto Imperial University, Series B 2(5): 259-311. 
Uéno M. 1940. Cladocera of Manchoukuo. Phyllopoda of Manchoukuo. Report of the

1082 Limnological Survey of Kwantung and Manchoukuo, Dairen: 323-367.

1083

Umetsu K, Iwabuchi N, Yuasa I, Saitou N, Clark PF, Boxshall G, Osawa M,

1084

Igarashi K. 2002. Complete mitochondrial DNA sequence of a tadpole shrimp (Triops

1085

cancriformis) and analysis of museum samples. Electrophoresis 23: 4080-4084.

1086

DOI 10.1002/elps.200290024

1087

Van Damme K, Sinev AY, Dumont HJ. 2011. Separation of Anthalona gen.n. from

Alona Baird, 1843 (Branchiopoda: Cladocera: Anomopoda): morphology and evolution of

1089 scraping stenothermic alonines. Zootaxa 2875: 1-64.

1090

DOI 10.11646/zootaxa.2875.1.1

1091

Xiang XF, Ji GH, Chen SZ, Yu GL, Xu L, Han BP, Kotov AA, Dumont HJ. 2015.

1092

Check-List of Chinese Cladocera (Crustacea: Branchiopoda). Part 1. Haplopoda, Ctenopoda,

1093 Onychopoda and Anomopoda (families Daphniidae, Moinidae, Bosminidae, Ilyocryptidae).

1094 Zootaxa 3904: 1-27.

1095 Yang J, Zhang X, Zhang W, Sun J, Xie Y, Zhang Y, Burton G.A, Yu H. (2017).

1096 Indigenous species barcode database improves the identification of zooplankton. PloS one

1097 12(10).

1098 DOI 10.1371/journal.pone.0185697

1099 Yoon SM. 2010. Arthropoda: Branchiopoda: Anostraca, Notostraca, Spinicaudata,

1100 Laevicaudata, Ctenopoda, Anomopoda, Haplopoda Branchiopods. Invertebrate fauna of Korea

1101 21(2): 1-156. 
1103

1104

1105

1106

1107

1108

1109

1110

1111

1112

1113

1114

1115

1116

1117

1118

1119

1120

1121

1122

1123

1124

\section{Captions}

\section{Figure 1. Map of populations of Scapholeberis and Megafenestra studied here}

genetically. Symbols correspond to mitochondrial clades (see Figure 2): (A) populations of the

S. mucronata species group (northern hemisphere); (B) populations of the $S$. rammneri species

group in the northern hemisphere; (C) populations of the $S$. freyi species group (western hemisphere); (D) populations of Megafenestra (clear symbols), S. microcephala, S. smirnovi

sp.nov., S. armata, S. cf. microcephala in northern hemisphere; (E) all populations studied in southern hemisphere. The base maps are from the public domain atlas in the desktop app, Marble 2.2.20 (http://edu.kde.org/marble). Symbols were placed manually using the output from DIVAGIS 7.5 (https://www.diva-gis.org/) as a guide. Note that the base maps and symbols are basically same as in Taylor et al. (2020), but only localities are represented from where the COI sequences were obtained here in addition to Taylor et al. (2020).

(1)



region of mitochondrial DNA in clades of neustonic daphniids (Scapholebeberinae).

1128 Horizontal bars indicate means. Gray rectangles show the ranges. See Appendix S1 for

1129 individual sequences.

1130

from Farm Dam, New South Wales, Australia. A-D, Adult parthenogenetic females, E,

1133 Juvenile parthenogenetic female, F-H, Ephippial females. A, Parthenogenetic female, lateral

1134 view. B, Adult parthenogenetic female, dorsal view. C, Head, ventral view. D, Labrum. E,

1135 Juvenile parthenogenetic female, lateral view. F, Ephippial female, lateral view. G, Ephippial

1136 female, dorsal view. H, Ornamentation of ephippium. Scale bars $=0.1 \mathrm{~mm}$.

New South Wales, Australia. A, Valve, ventral view. B-C, Armature of valve. D-E,

1140 Posteroventral portion of valve, inner view. F-G, Postabdomen. H-I, Postabdominal claw. J-K,

1141 Antenna I. L-M, Antenna II. Scale bars $=0.1 \mathrm{~mm}$. 
from Farm Dam, New South Wales, Australia. A-E, Parthenogenetic females, F-L, Ephippial

1149 females. A, Ephippial female, lateral view. B, Valve, inner view. C, Posteroventral portion of

1150 valve, inner view. D, Head, ventral view. E, Antenna I. F, I, Ephippial females, lateral view. G, J,

1151 Ephippia, lateral view. K, Head, lateral view. H, L, Ornamentation of central portion of ephippia.

1152 Scale bars $=0.2 \mathrm{~mm}$ for A-B, F-G, I-J, $0.1 \mathrm{~mm}$ for D, K, $0.05 \mathrm{~mm}$ for H, $0.02 \mathrm{~mm}$ for C, E, L.

South Wales, Australia. A, Ephippial female, dorsal view. B, Ephippium, dorsal view. C,

1156 Ephippium, dorsal view on higher magnification. D, Head, dorsal view. E, Ephippial female,

1157 ventral view. F, Head, ventral view. G, Head on higher magnification, ventral view. Scale bars =

$11580.2 \mathrm{~mm}$ for $\mathrm{A}-\mathrm{B}, \mathrm{E}, 0.1 \mathrm{~mm}$ for $\mathrm{C}-\mathrm{D}, 0.05 \mathrm{~mm}$ for $\mathrm{F}-\mathrm{G}$.

Figure 9. Scapholeberis kingii Sars, 1888, preephippial female from the roadside pool near Lake Bantic, West Coast, Tasmania, Australia. A, Preephippial female, lateral view. B, Head, lateral view. C, Postabdominal claw, lateral view. D, Posterior portion of body.

1163 E-F, Posterior portion of body on higher magnifications. Scale bars $=0.2 \mathrm{~mm}$ for A, D, $0.1 \mathrm{~mm}$

1164 for B, E, $0.05 \mathrm{~mm}$ for $\mathrm{F}, 0.02 \mathrm{~mm}$ for $\mathrm{C}$.

1167 Collectio Dadayana. A, Adult parthenogenetic female, lateral view (DAD 10-70-159). B,

1168 Juvenile parthenogenetic female, lateral view (DAD 10-70-156). C, Head, dorsal (?) view (DAD 1169 10-70-156). D, Antenna II (DAD 10-70-156). Scale bars $=0.1 \mathrm{~mm}$. 
1172 Bahir Dar Bay of Lake Tana, Amhara, Ethiopia. A, Parthenogenetic female, lateral view. B,

1173 Head, lateral view. C, Head, ventral view. D, Labrum. E, Valve. F-H, Armature of

1174 posteroventral angle of valve. I, Postabdomen. J, Distal portion of postabdomen. K,

1175 Postabdominal seta. L, Antenna I. Scale bars $=0.1 \mathrm{~mm}$.

1176

1177

1178

Figure 12. Scapholeberis cf. intermedius Daday, 1898, a parthenogenetic female from Bahir Dar Bay of Lake Tana, Amhara, Ethiopia. A, Distal portion of postabdomen. B, Antenna II. D-J, Fragments of antenna II. K, Thoracic limb I. Scale bars $=0.1 \mathrm{~mm}$.

Bahir Dar Bay of Lake Tana, Amhara, Ethiopia. A, Thoracic limb I. B, Thoracic limb II. C-

1184 Scale bars $=0.1 \mathrm{~mm}$.

1185

1186

Figure 15. Scapholeberis cf. intermedius Daday, 1898, a parthenogenetic female from Bahir Dar Bay of Lake Tana, Amhara, Ethiopia. A, Parthenogenetic female, lateral view. B, 
1192 Anterior portion of body. C, Head, lateral view. D, Posterior portion of body. E, Ornamentation

1193 of valve. Scale bars $0.2 \mathrm{~mm}$ for $\mathrm{A}, \mathrm{D}, 0.1 \mathrm{~mm}$ for $\mathrm{B}, 0.05 \mathrm{~mm}$ for C, E.

1194

1195

Figure 16. Scapholeberis smirnovi sp.nov. from the puddle near Lake Maloe Utinoe,

Primorski Territory, Far East, Russia. A-D, Adult parthenogenetic females, E-F, Juvenile

1197

parthenogenetic female, G-I, Ephippial females. A, Adult parthenogenetic female, lateral view.

1198

B, Parthenogenetic female, dorsal view. C, Head, ventral view. D, Labrum. E, Juvenile

1199

parthenogenetic female. F, Head, ventral view. G, Ephippial female, lateral view. H, Ephippial

1200

female, dorsal view. I, Ornamentation of ephippium. Scale bars $=0.1 \mathrm{~mm}$.

1201

1202

Figure 17. Scapholeberis smirnovi sp.nov. from the puddle near Lake Maloe Utinoe,

Primorski Territory, Far East, Russia. A, Valve, outer view. B, Valve, ventral view. C-D,

Armature of valve. E, Posteroventral portion of valve, inner view. F-H, Postabdomen. I,

Postabdominal claw. J-K, Antenna I. L-M, Antenna II. Scale bars $0.1=\mathrm{mm}$.

1206

1207

Figure 18. Scapholeberis smirnovi sp.nov. from the puddle near Lake Maloe Utinoe,

Primorski Territory, Far East, Russia. A-B, Thoracic limb I. C-D, Thoracic limb II. E,

Thoracic limb III. F-G, Thoracic limb IV. H, Thoracic limb V. Scale bar $=0.1 \mathrm{~mm}$.

Figure 19. Scapholeberis smirnovi sp.nov., ephippial and preephippial females from

1213 Ephippial females, C, Preephippial female. A, Ephippial female, lateral view. B, Ephippium,

1214 lateral view. C, Preephippial female, lateral view. D, Ephippial female, anterodorsal view. E, 
1215 Ephippium, anterodorsal view. F, Ephippial female, ventral view. Scale bars $=0.2 \mathrm{~mm}$ for A-D, 1216 F, $0.1 \mathrm{~mm}$ for E.

1217

1218

Figure 20. Scapholeberis smirnovi sp.nov., ephippial females from a pond in

1219 Choenggye Mountains, Seoul, the Republic of South Korea. A, Ephippial female, lateral

1220 view. B-C, Head, lateral view. D, Ephippium, lateral view. E-F, Ornamentation of ephippium.

1221 G, Ephippial female, dorsal view. H, Head, dorsal view. I-J, Ephippium, dorsal view. K-L,

1222 Armature of ephippium on higher magnifications. Scale bars $=0.2 \mathrm{~mm}$ for A, D, G, I, $0.1 \mathrm{~mm}$

1223 for B-C, H, J-L, $0.5 \mathrm{~mm}$ for $\mathrm{F}, 0.2 \mathrm{~mm}$ for $\mathrm{E}$.

1224

1225

Figure 21. Analysis of identification for four species groups of Scapholeberis based on GenBank data. group in Eurasia based on morphological characters. 
1231

1232

Peer) reviewing PDF | (2020:04:48120:2:0:NEW 24 Oct 2020) 


\section{Figure 1}

Map of populations of Scapholeberis and Megafenestra studied here genetically.

Symbols correspond to mitochondrial clades (see Figure 2): (A) populations of the $S$.

mucronata species group (northern hemisphere); (B) populations of the $S$. rammneri species group in the northern hemisphere; (C) populations of the $S$. freyi species group (western hemisphere); (D) populations of Megafenestra (clear symbols), S. microcephala, S. smirnovi sp.nov., S. armata, S. cf. microcephala in northern hemisphere; (E) all populations revealed in southern hemisphere. The base maps are from the public domain atlas in the desktop app, Marble 2.2.20 ( http://edu.kde.org/marble ). Symbols were placed manually in Microsoft PowerPoint using the output from DIVA-GIS 7.5 ( https://www.diva-gis.org/) as a guide. Note that the base maps and symbols are basically same as in Taylor et al. (2020), but just the only localities are represented from where the $\mathrm{COI}$ sequences were obtained here in addition to Taylor et al. (2020). 

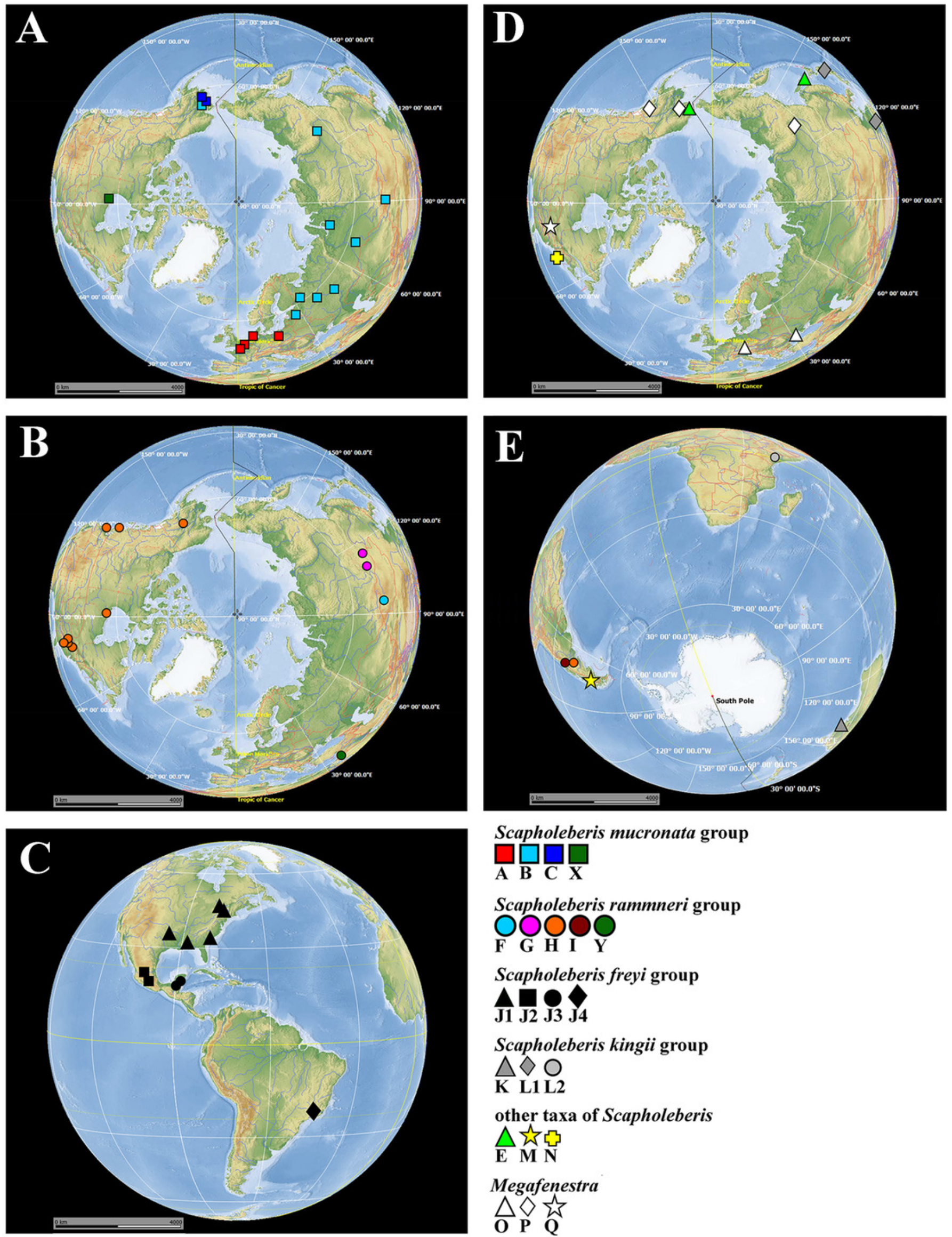

Scapholeberis mucronata group $\square \square \square \square$

Scapholeberis rammneri group $\mathrm{O}_{\mathbf{F}} \mathrm{OOO}_{\mathbf{Y}}$

Scapholeberis freyi group

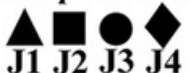

Scapholeberis kingii group $\triangle \diamond \bigcirc$

other taxa of Scapholeberis $\triangle$ 嵌鸟

Megafenestra $\triangle \stackrel{\sim}{\mathbf{P}}$ 
Figure 2

Maximum likelihood mitochondrial phylogeny of neustonic daphniids (Scapholeberis and Megafenestra).

Bold letters $(A-Q, X-Y)$ indicate geographic clades. Numbers at the nodes indicate Bayesian posterior probabilities and Transfer Bootstrap Expectations (TBE). Colours represent major species groups in the Scapholeberinae: Scapholeberis mucronata group (green), S. rammneri group (red), S. freyi group (black), S. kingii group (grey), S. armata-microcephala clade (blue), genus Megafenestra (white). The tree is outgroup-rooted using sequences from the genus Megafenestra. See Appendix S1 for individual sequences.

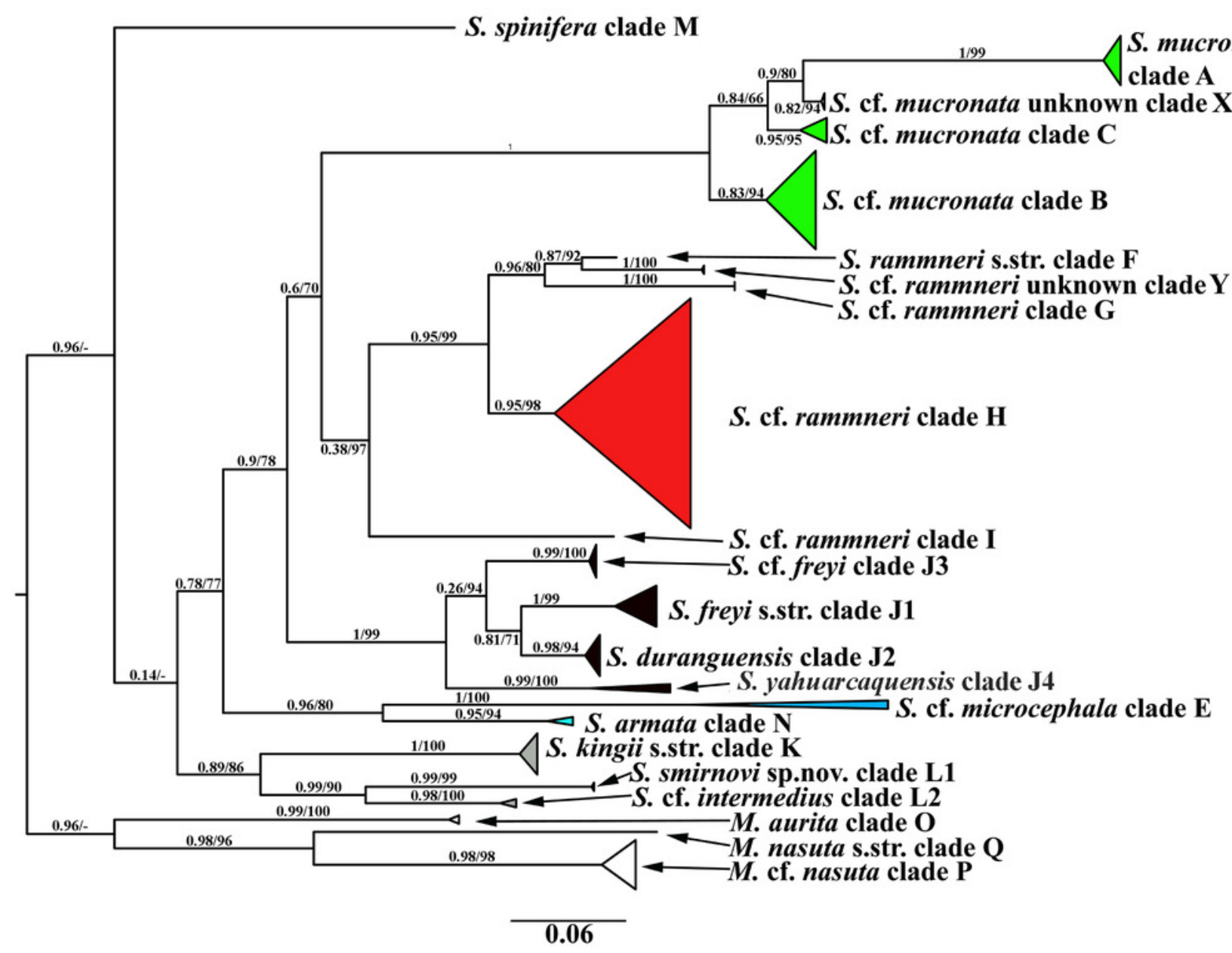


Figure 3

Violin plots of pairwise Kimura's 2 Parameter Distances from the COI region of mitochondrial DNA in clades of neustonic daphniids (Scapholebeberinae).

Horizontal bars indicate means. Gray rectangles show the ranges. Taxa are genera or species groups in the Scapholeberinae. See Appendix S1 for individual sequences.

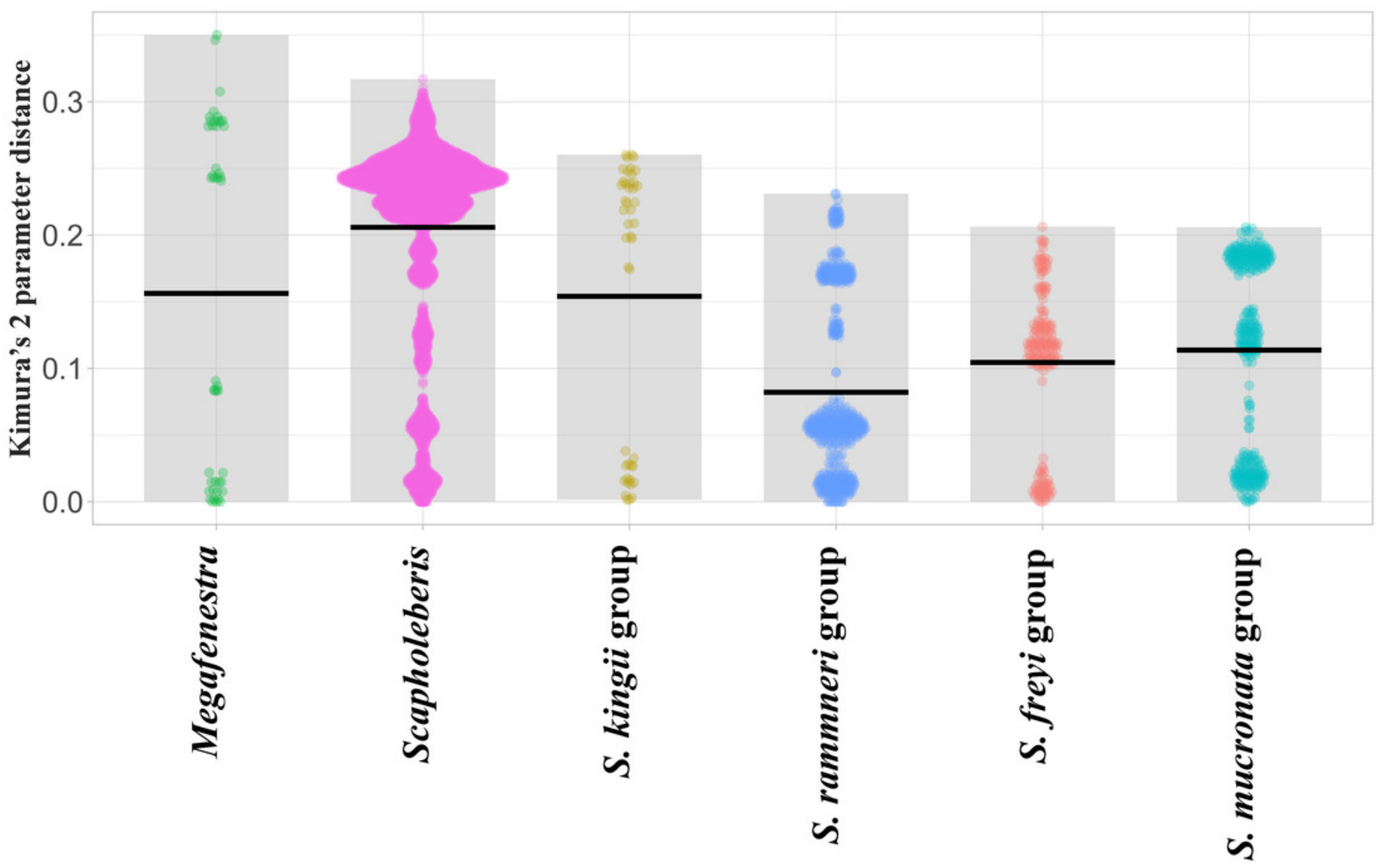




\section{Figure 4}

Scapholeberis kingii Sars, 1888, parthenogenetic and ephippial females from Farm Dam, New South Wales, Australia.

A-D, Adult parthenogenetic females, E, Juvenile parthenogenetic female, F-H, Ephippial females. A, Parthenogenetic female, lateral view. B, Adult parthenogenetic female, dorsal view. C, Head, ventral view. D, Labrum. E, Juvenile parthenogenetic female, lateral view. F, Ephippial female, lateral view. G, Ephippial female, dorsal view. H, Ornamentation of ephippium. Scale bars $=0.1 \mathrm{~mm}$. 


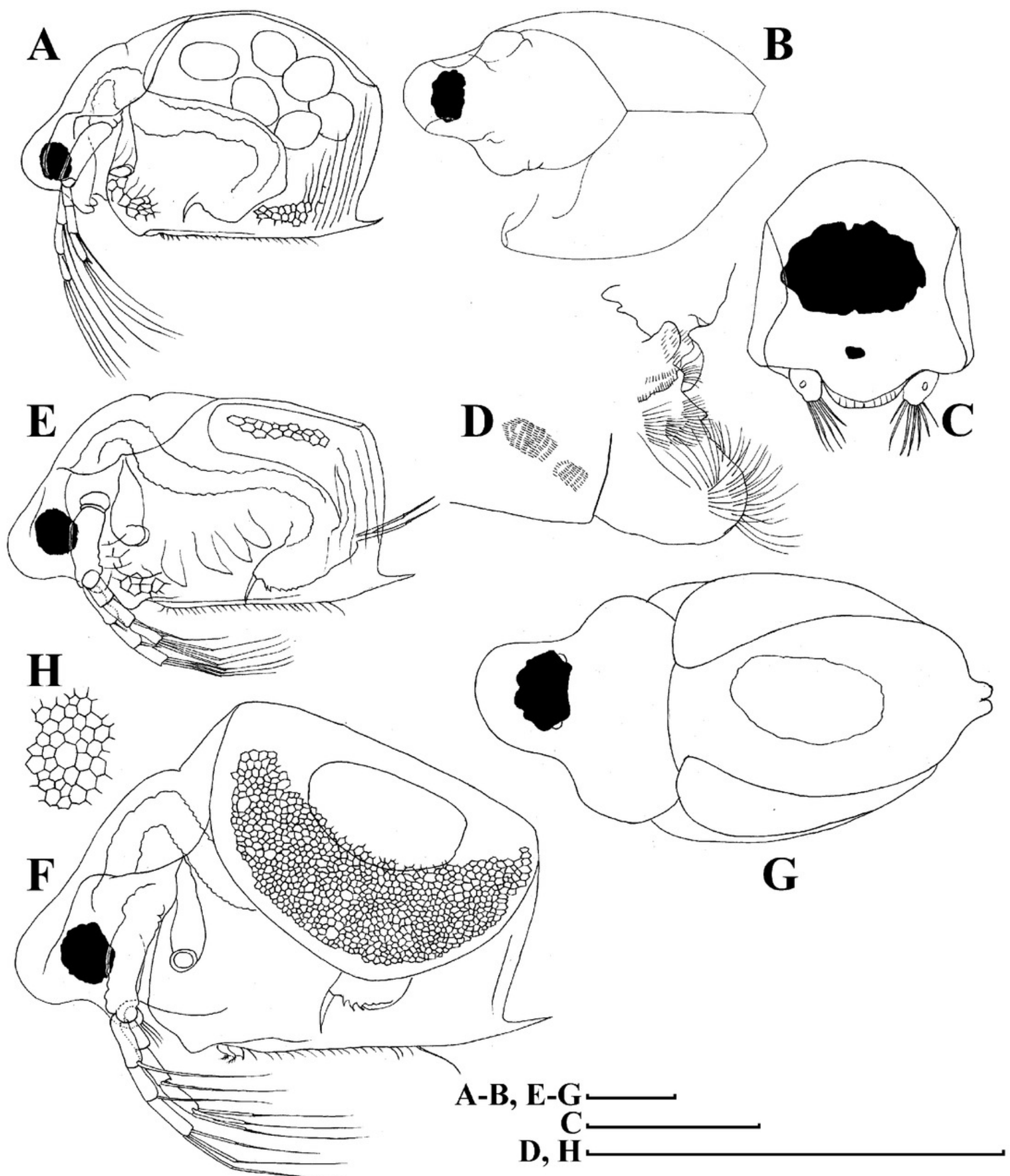


Figure 5

Scapholeberis kingii Sars, 1888, parthenogenetic females from Farm Dam, New South Wales, Australia.

A, Valve, ventral view. B-C, Armature of valve. D-E, Posteroventral portion of valve, inner view. F-G, Postabdomen. H-I, Postabdominal claw. J-K, Antenna I. L-M, Antenna II. Scale bars $=0.1 \mathrm{~mm}$. 


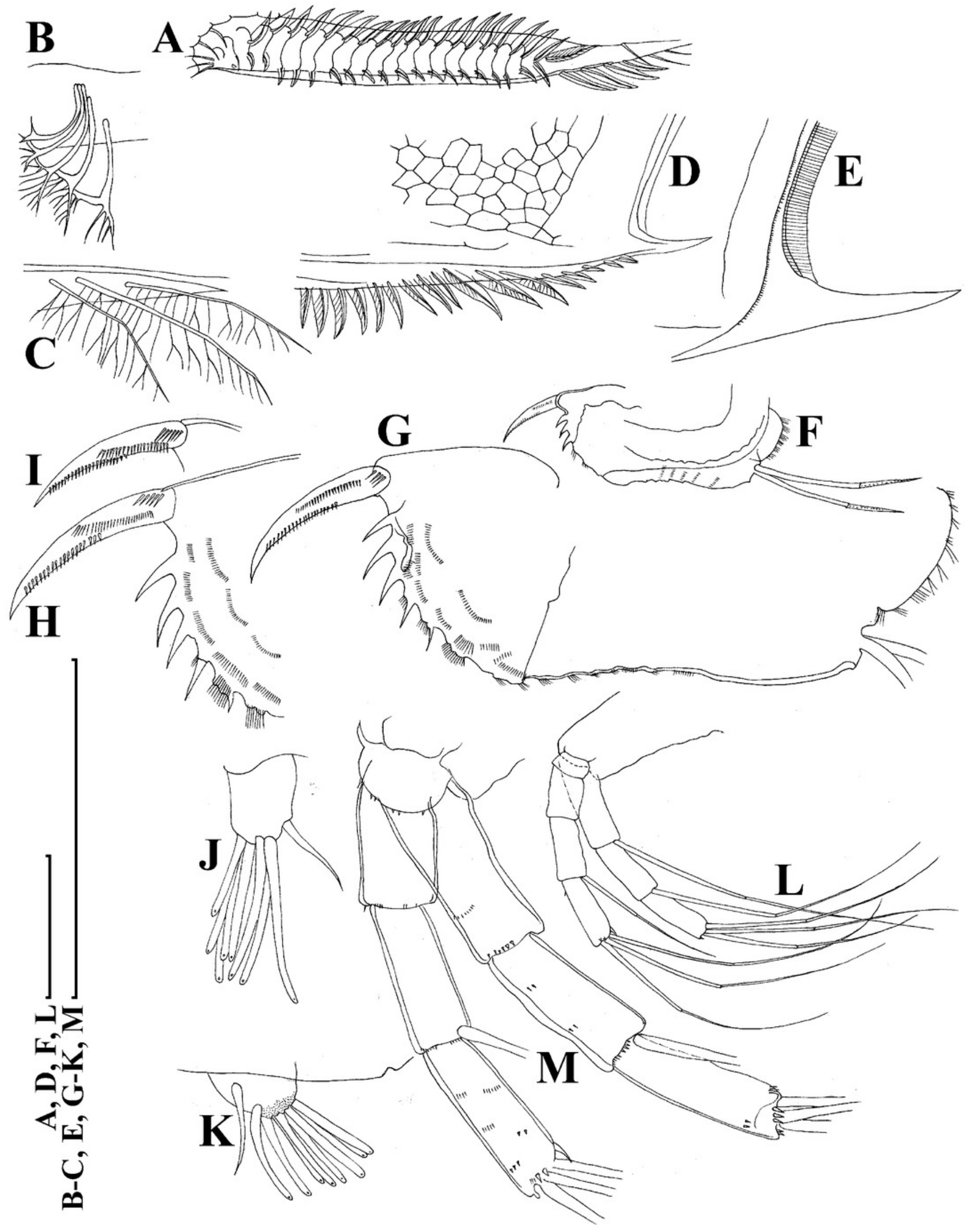


Figure 6

Scapholeberis kingii Sars, 1888, parthenogenetic females from Farm Dam, New South Wales, Australia.

A, Thoracic limb I. B, Thoracic limb II. C, Thoracic limb III. D, Thoracic limb IV. E, Thoracic limb

V. Scale bar $=0.1 \mathrm{~mm}$. 


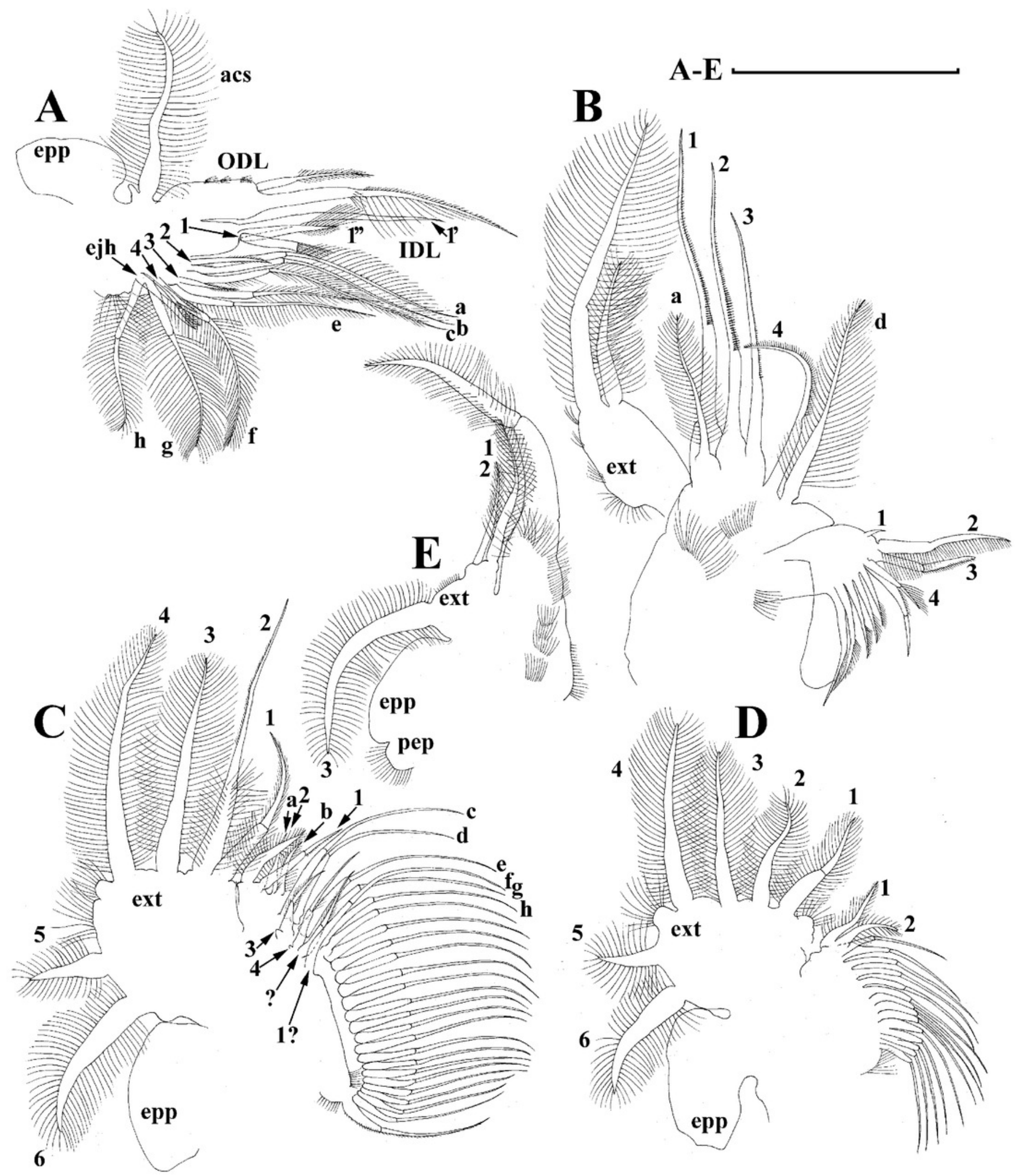




\section{Figure 7}

Scapholeberis kingii Sars, 1888, parthenogenetic and ephippial females from Farm Dam, New South Wales, Australia.

A-E, Parthenogenetic females, F-L, Ephippial females. A, Ephippial female, lateral view. B, Valve, inner view. C, Posteroventral portion of valve, inner view. D, Head, ventral view. E, Antenna I. F, I, Ephippial females, lateral view. G, J, Ephippia, lateral view. K, Head, lateral view. $\mathrm{H}, \mathrm{L}$, Ornamentation of central portion of ephippia. Scale bars $=0.2 \mathrm{~mm}$ for A-B, F-G, I-J, $0.1 \mathrm{~mm}$ for $\mathrm{D}, \mathrm{K}, 0.05 \mathrm{~mm}$ for $\mathrm{H}, 0.02 \mathrm{~mm}$ for $\mathrm{C}, \mathrm{E}, \mathrm{L}$. 

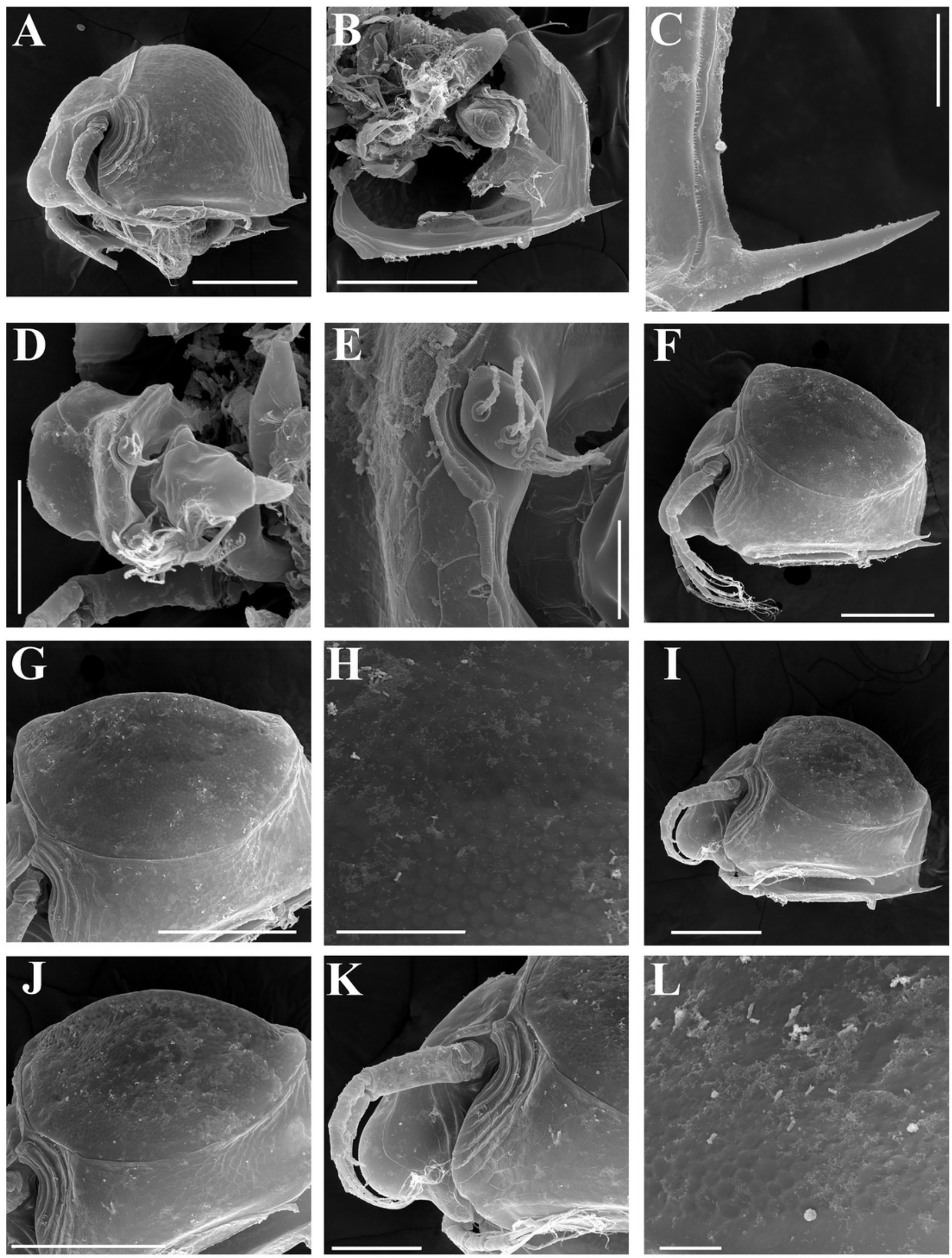


\section{Figure 8}

Scapholeberis kingii Sars, 1888, ephippial females from Farm Dam, New South Wales, Australia.

A, Ephippial female, dorsal view. B, Ephippium, dorsal view. C, Ephippium, dorsal view on higher magnification. D, Head, dorsal view. E, Ephippial female, ventral view. F, Head, ventral view. $G$, Head on higher magnification, ventral view. Scale bars $=0.2 \mathrm{~mm}$ for $A-B, E, 0.1 \mathrm{~mm}$ for C-D, $0.05 \mathrm{~mm}$ for F-G.
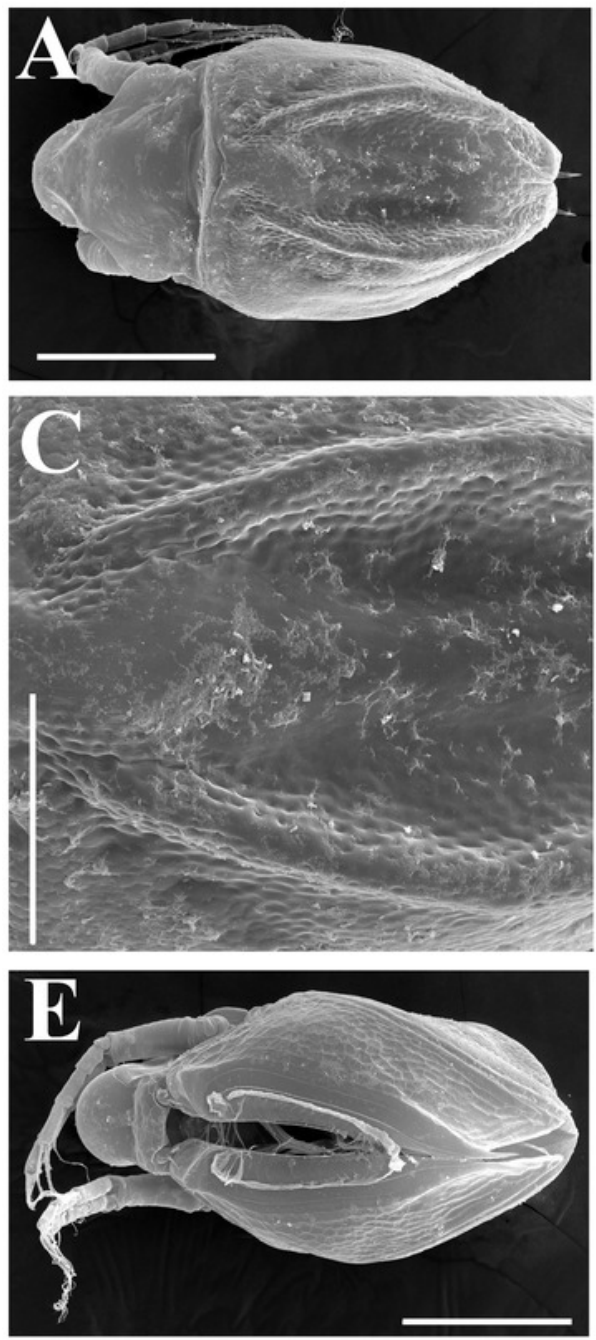
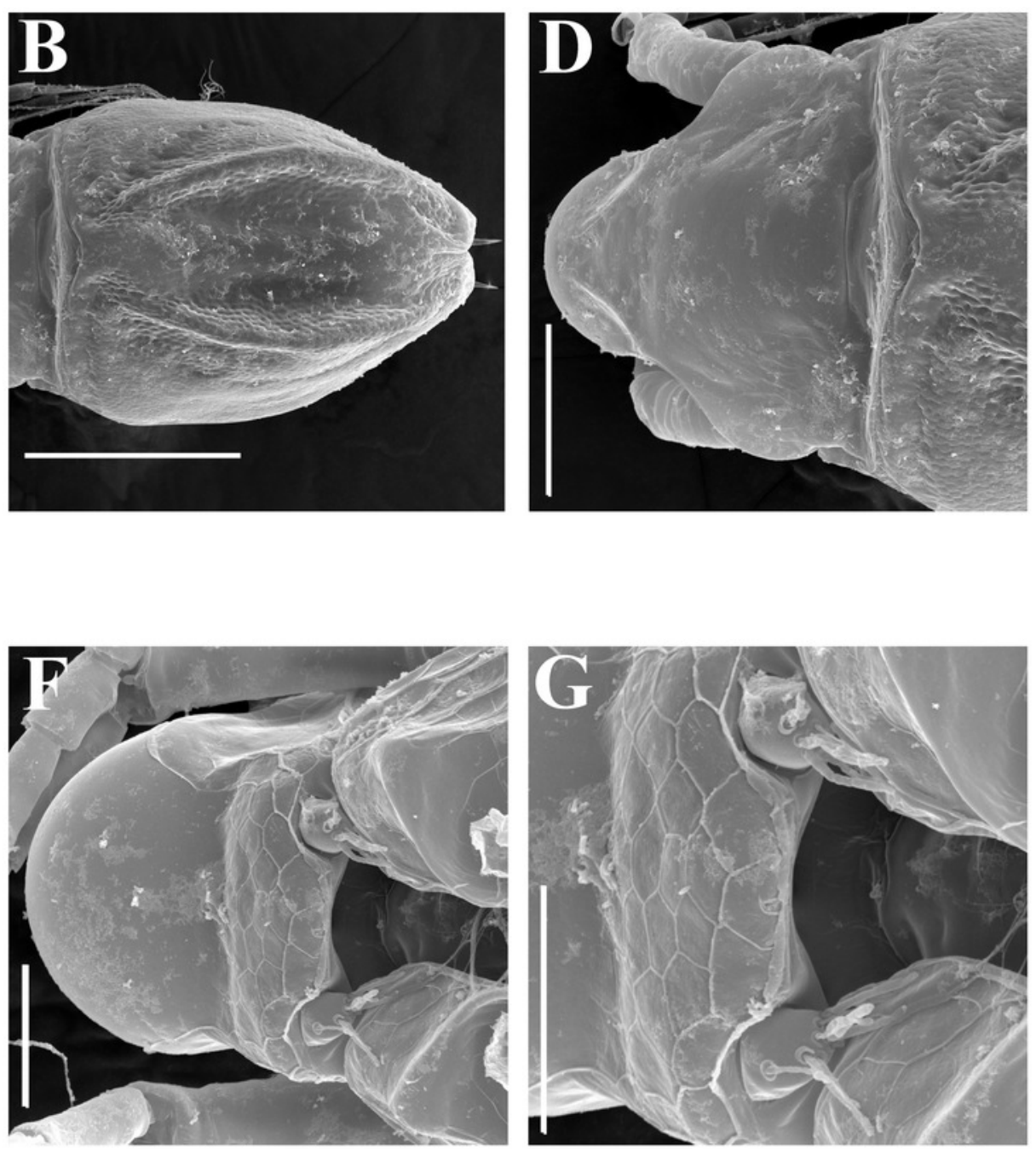


\section{Figure 9}

Scapholeberis kingii Sars, 1888, preephippial female from the roadside pool near Lake Bantic, West Coast, Tasmania, Australia.

A, Preephippial female, lateral view. B, Head, lateral view. C, Postabdominal claw, lateral view. D, Posterior portion of body. E-F, Posterior portion of body on higher magnifications. Scale bars $=0.2 \mathrm{~mm}$ for $A, D, 0.1 \mathrm{~mm}$ for $B, E, 0.05 \mathrm{~mm}$ for $F, 0.02 \mathrm{~mm}$ for $C$.
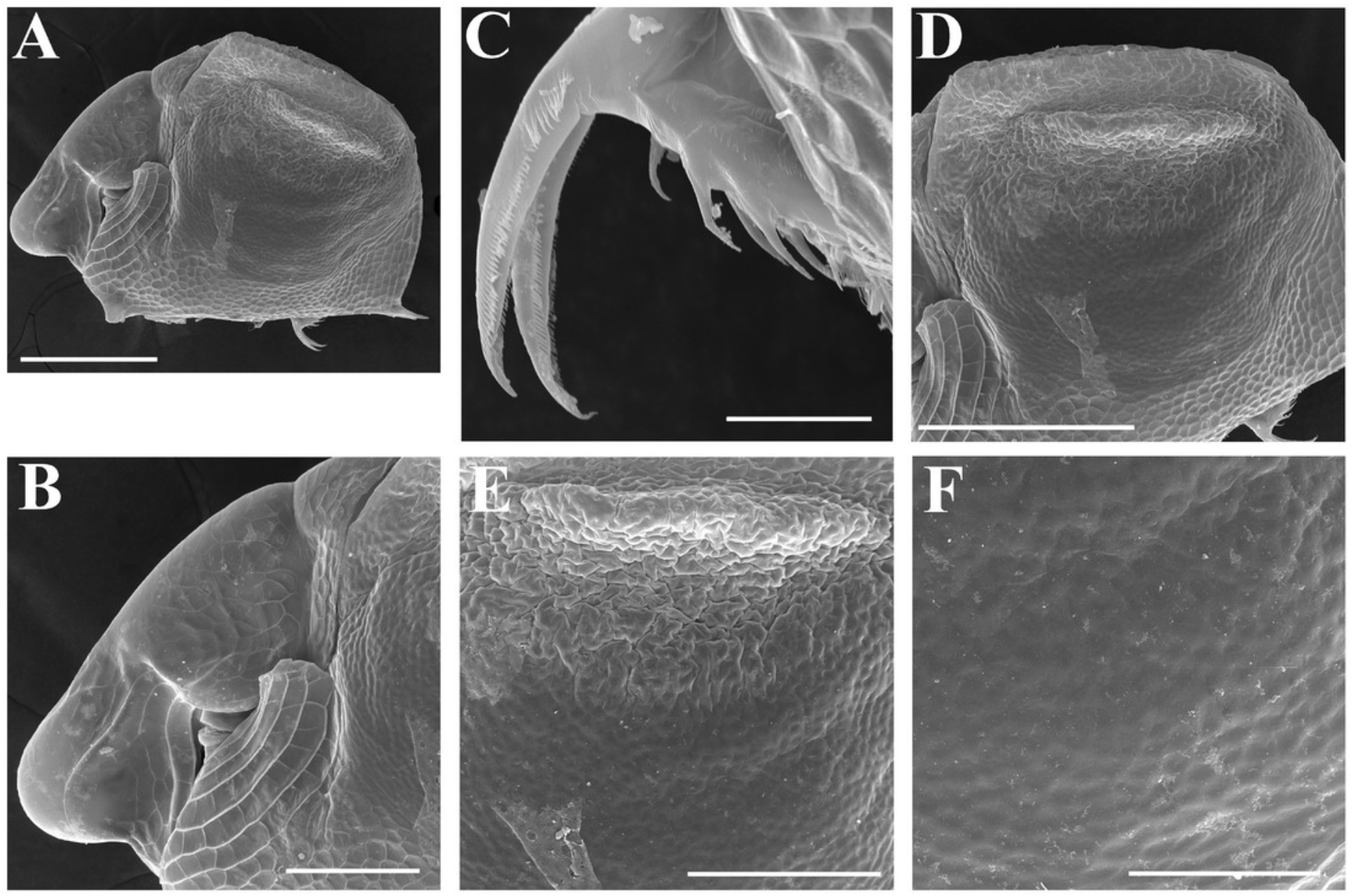


\section{Figure 10}

Scapholeberis intermedius Daday, 1898, parthenogenetic females from Collectio Dadayana.

A, Adult parthenogenetic female, lateral view (DAD 10-70-159). B, Juvenile parthenogenetic female, lateral view (DAD 10-70-156). C, Head, dorsal (?) view (DAD 10-70-156). D, Antenna II (DAD 10-70-156). Scale bars $=0.1 \mathrm{~mm}$.
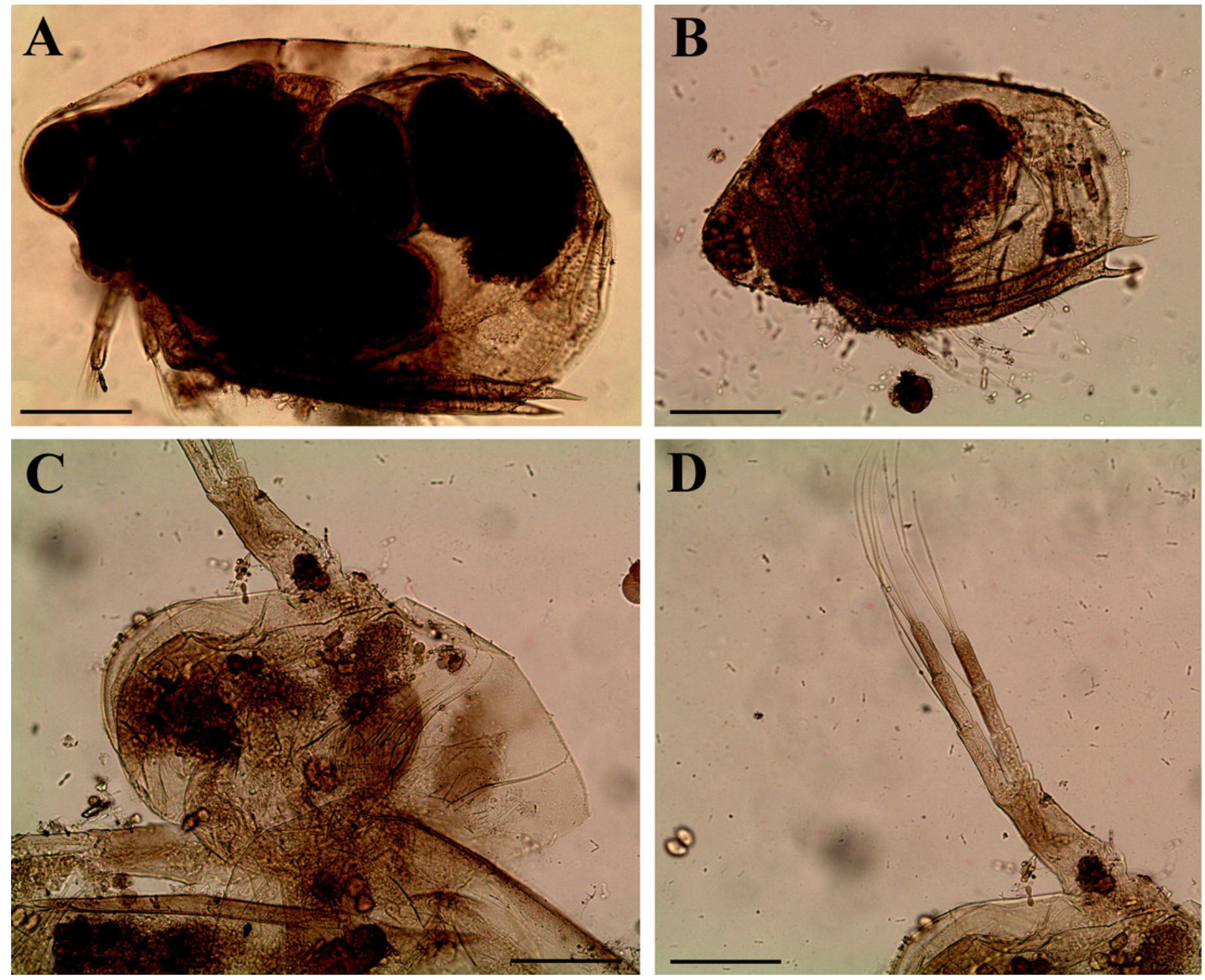


\section{Figure 11}

Scapholeberis cf. intermedius Daday, 1898, a parthenogenetic female from Bahir Dar Bay of Lake Tana, Amhara, Ethiopia.

A, Parthenogenetic female, lateral view. B, Head, lateral view. C, Head, ventral view. D, Labrum. E, Valve. F-H, Armature of posteroventral angle of valve. I, Postabdomen. J, Distal portion of postabdomen. K, Postabdominal seta. L, Antenna I. Scale bars $=0.1 \mathrm{~mm}$. 


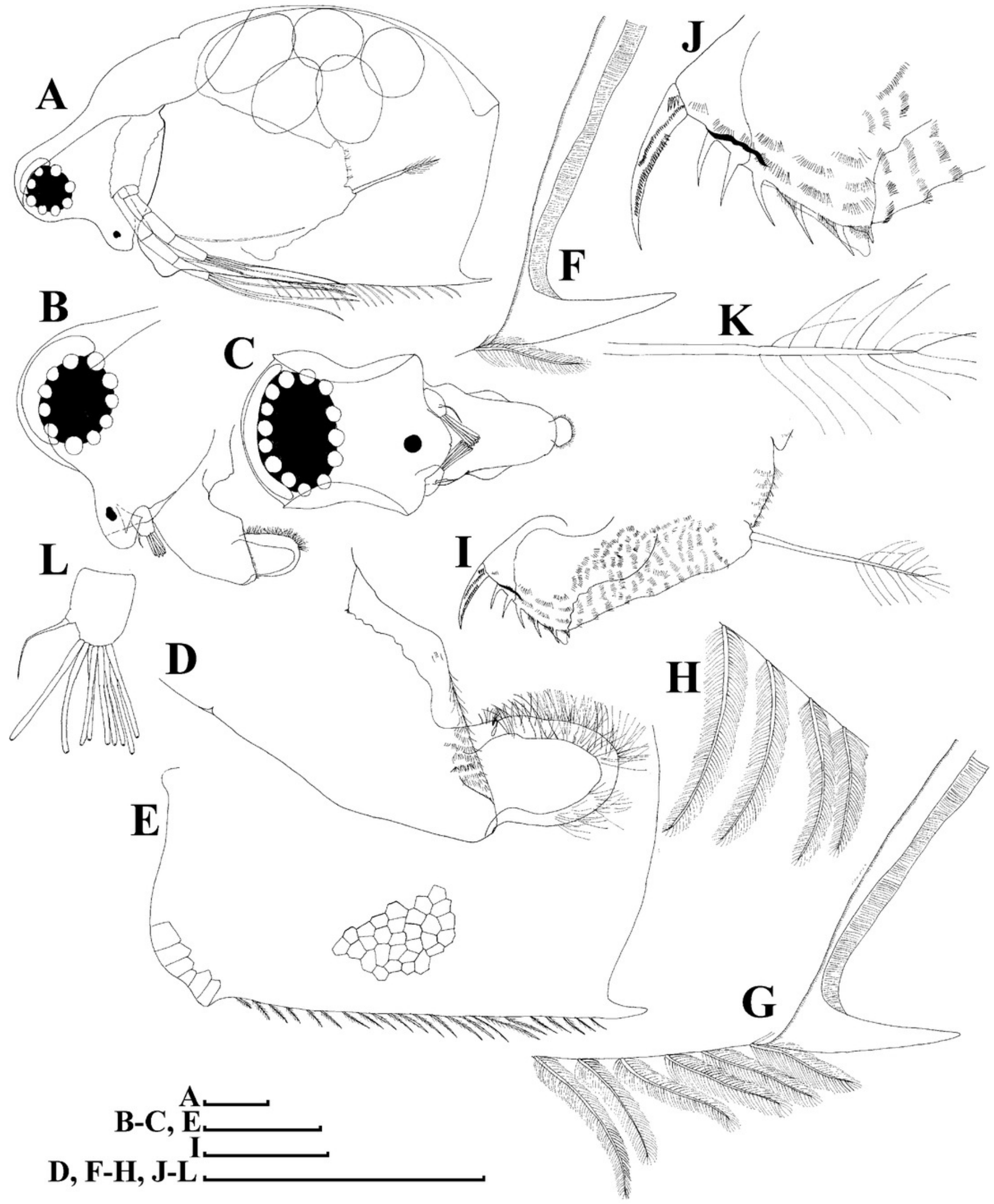




\section{Figure 12}

Scapholeberis cf. intermedius Daday, 1898, a parthenogenetic female from Bahir Dar Bay of Lake Tana, Amhara, Ethiopia.

A, Distal portion of postabdomen. B, Antenna II. D-J, Fragments of antenna II. K, Thoracic limb

I. Scale bars $=0.1 \mathrm{~mm}$. 


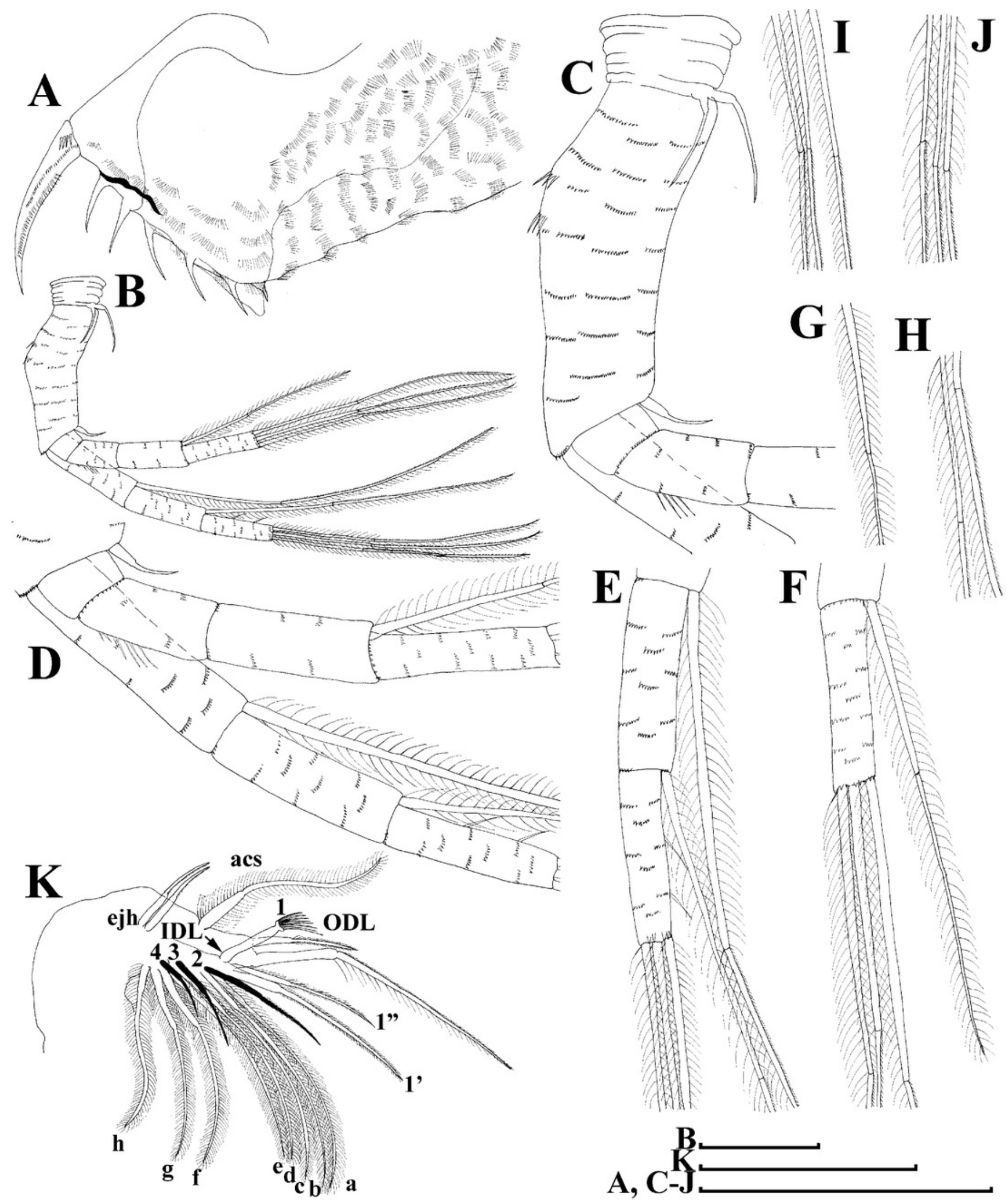


Figure 13

Scapholeberis cf. intermedius Daday, 1898, a parthenogenetic female from Bahir Dar Bay of Lake Tana, Amhara, Ethiopia.

A, Thoracic limb I. B, Thoracic limb II. C-D, Fragments of thoracic limb II. E, Thoracic limb III. F-G, Fragments of thoracic limb III. Scale bars $=0.1 \mathrm{~mm}$. 


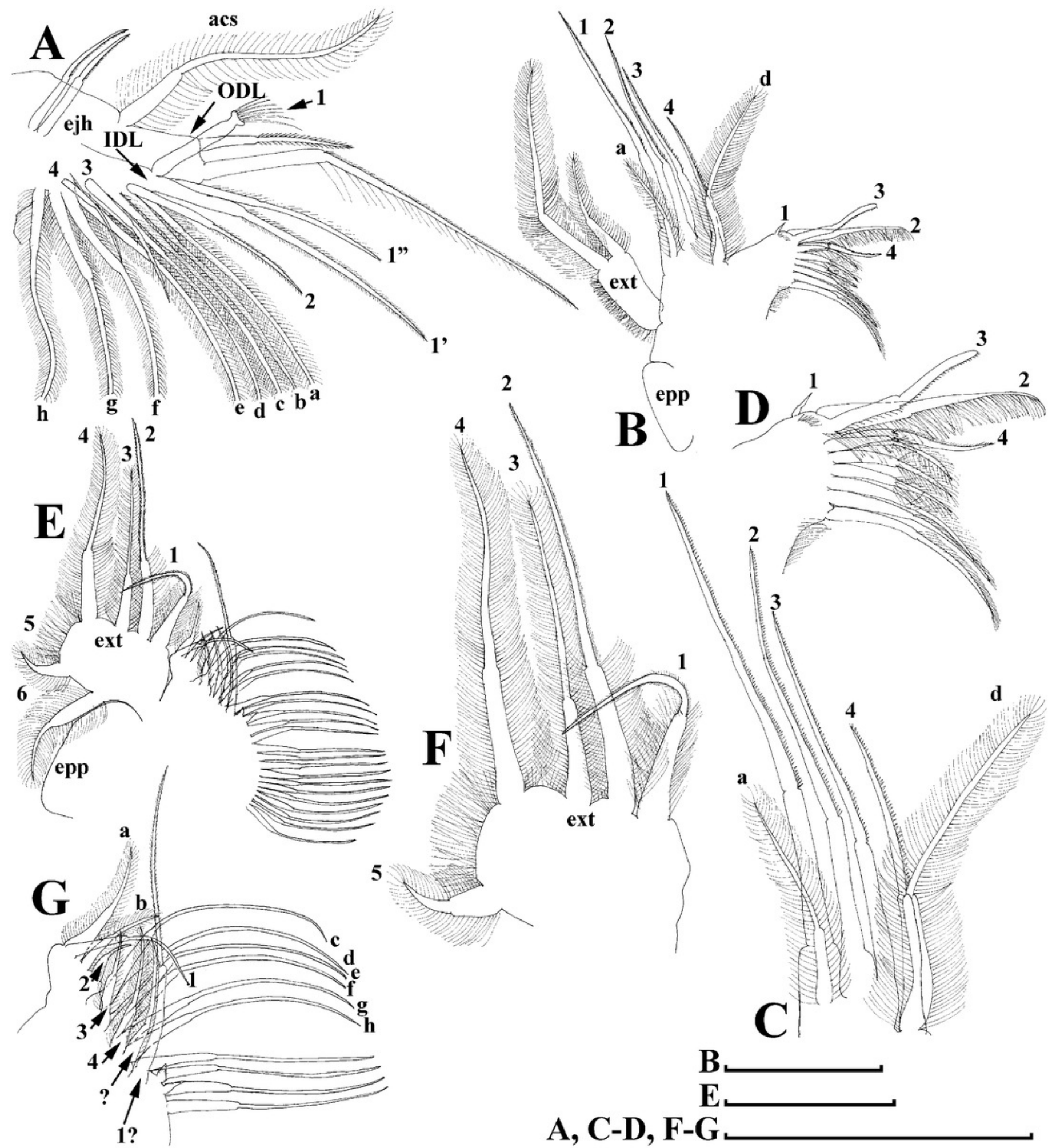


Figure 14

Figure 14. Scapholeberis cf. intermedius Daday, 1898, a parthenogenetic female from Bahir Dar Bay of Lake Tana, Amhara, Ethiopia.

A, Thoracic limb IV. B-C, Fragments of thoracic limb IV. D, Thoracic limb V. E, Fragment of thoracic limb V. Scale bars $=0.1 \mathrm{~mm}$.
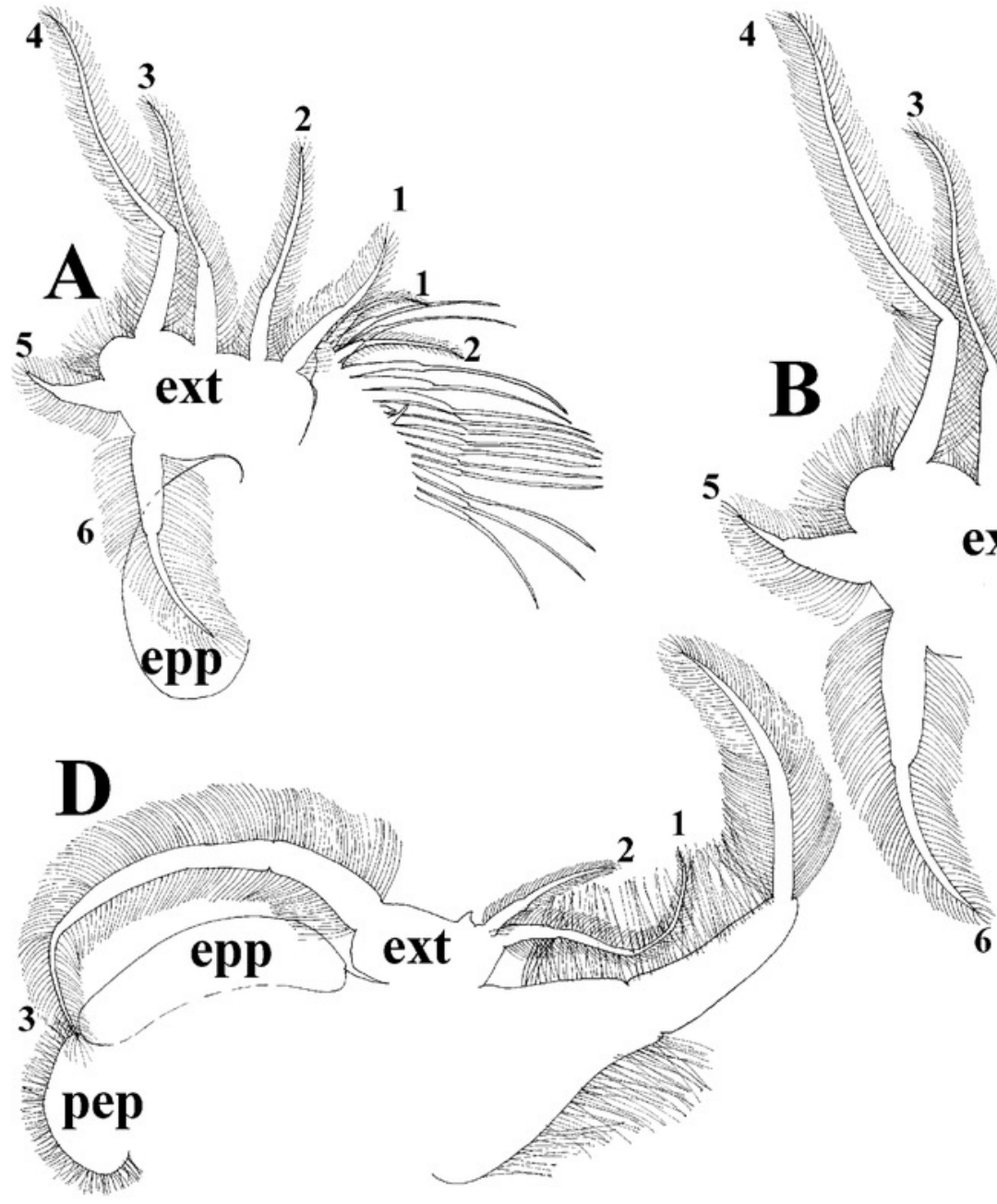

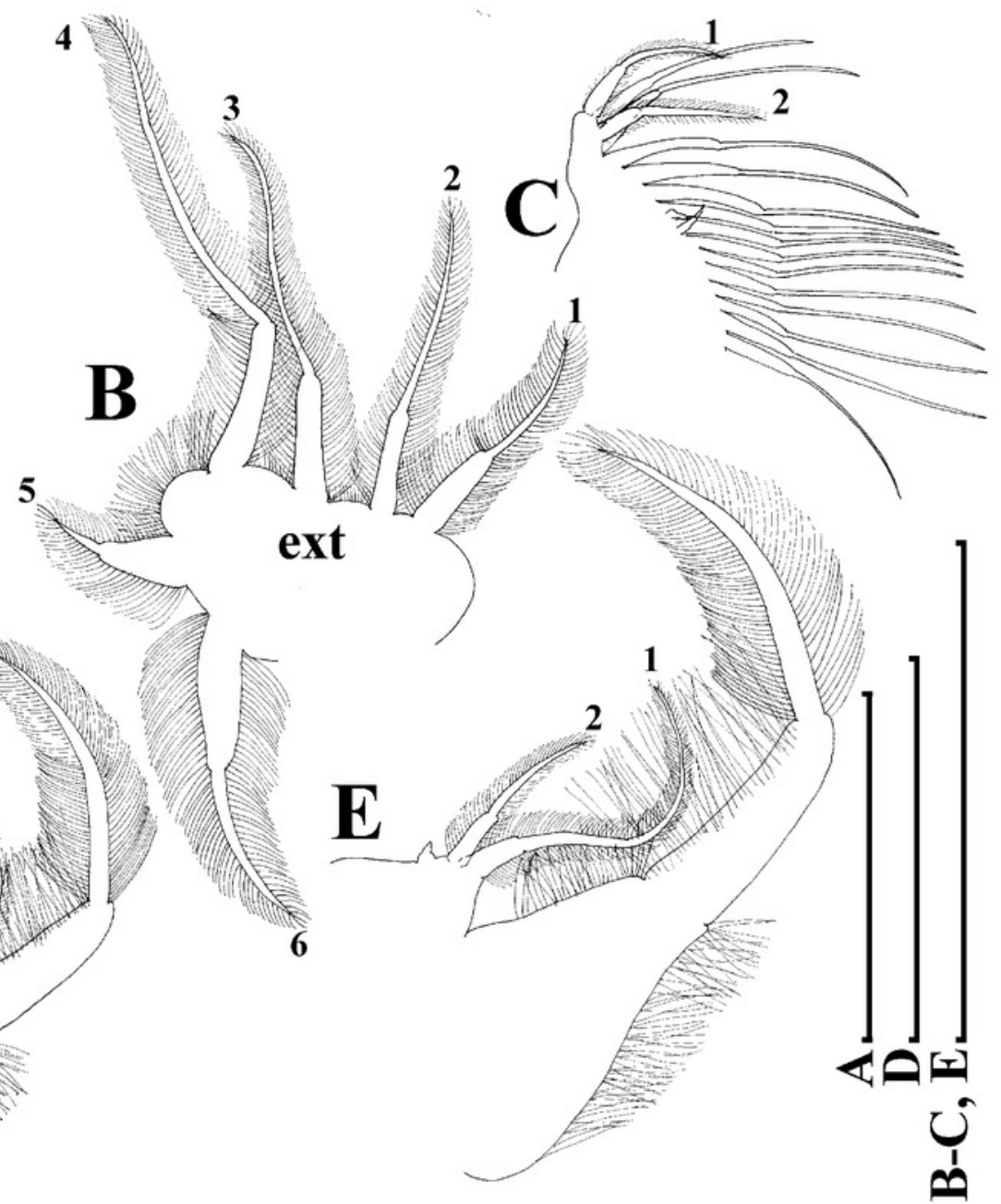




\section{Figure 15}

Scapholeberis cf. intermedius Daday, 1898, a parthenogenetic female from Bahir Dar Bay of Lake Tana, Amhara, Ethiopia.

A, Parthenogenetic female, lateral view. B, Anterior portion of body. C, Head, lateral view. D, Posterior portion of body. E, Ornamentation of valve. Scale bars $0.2 \mathrm{~mm}$ for $A, D, 0.1 \mathrm{~mm}$ for B, $0.05 \mathrm{~mm}$ for $\mathrm{C}, \mathrm{E}$.
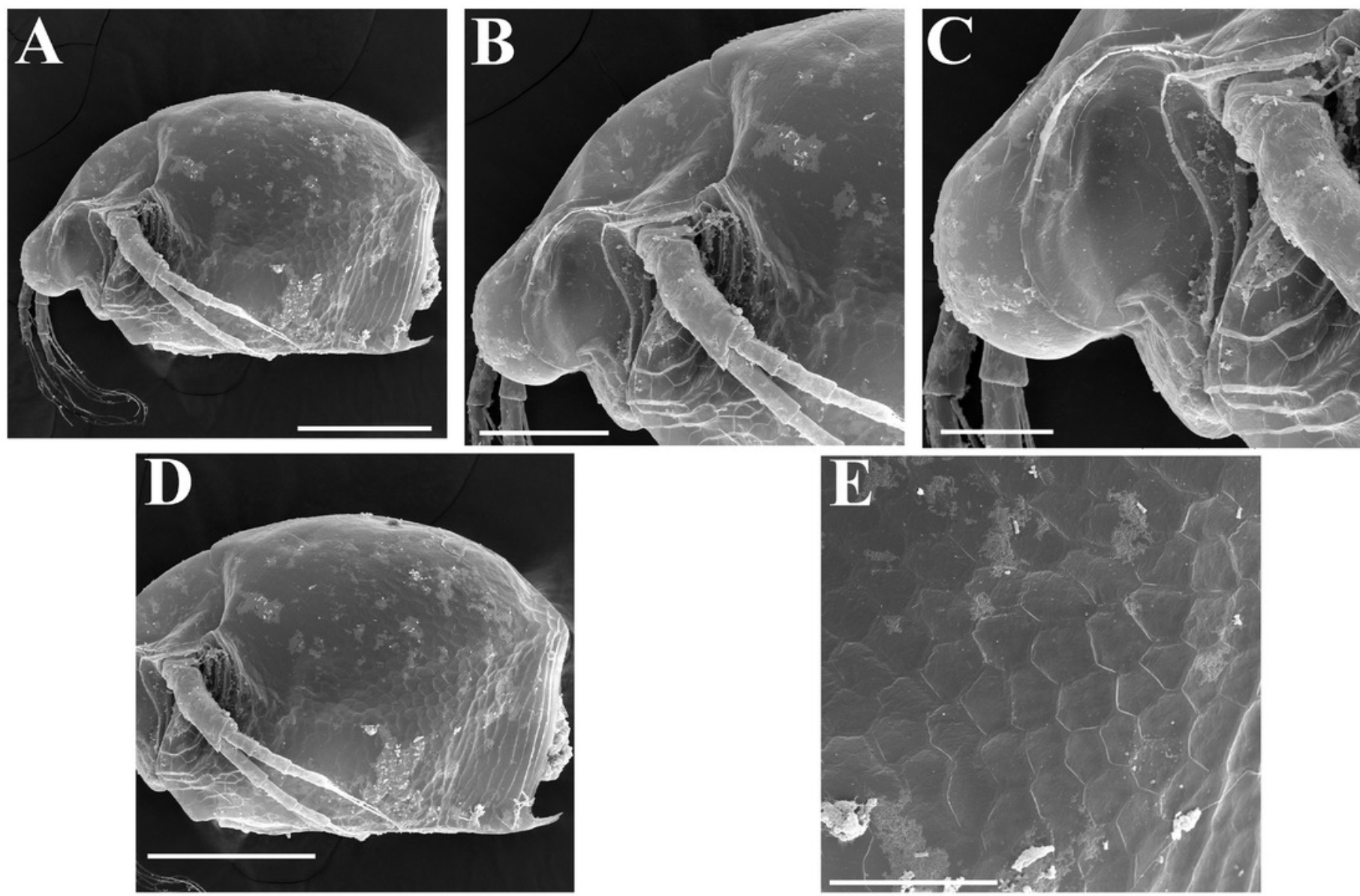


\section{Figure 16}

Scapholeberis smirnovi sp.nov. from the puddle near Lake Maloe Utinoe, Primorski Territory, Far East, Russia.

A-D, Adult parthenogenetic females, E-F, Juvenile parthenogenetic female, G-I, Ephippial females. A, Adult parthenogenetic female, lateral view. B, Parthenogenetic female, dorsal view. C, Head, ventral view. D, Labrum. E, Juvenile parthenogenetic female. F, Head, ventral view. G, Ephippial female, lateral view. H, Ephippial female, dorsal view. I, Ornamentation of ephippium. Scale bars $=0.1 \mathrm{~mm}$. 


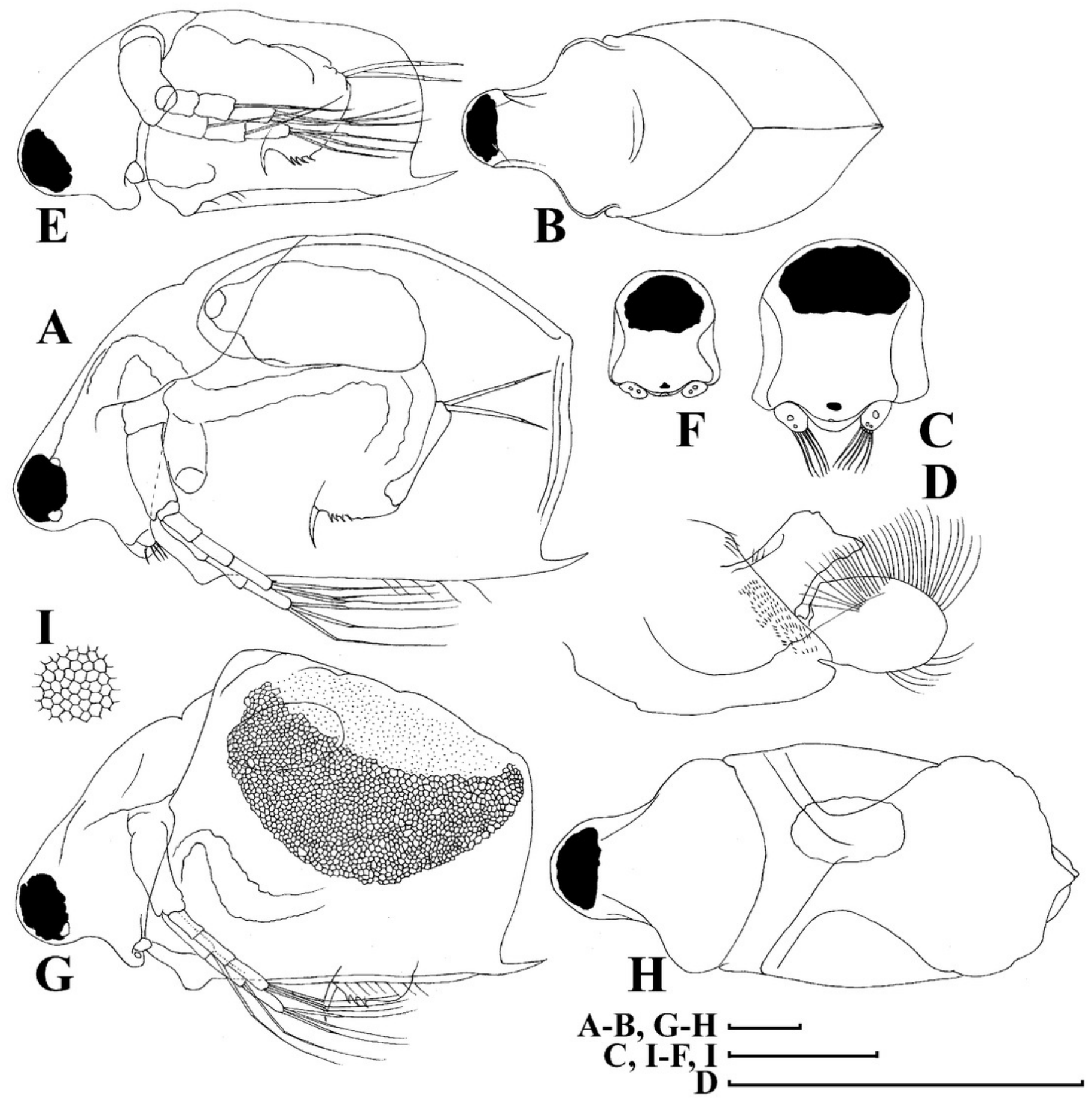




\section{Figure 17}

Scapholeberis smirnovi sp.nov. from the puddle near Lake Maloe Utinoe, Primorski Territory, Far East, Russia.

A, Valve, outer view. B, Valve, ventral view. C-D, Armature of valve. E, Posteroventral portion of valve, inner view. F-H, Postabdomen. I, Postabdominal claw. J-K, Antenna I. L-M, Antenna II. Scale bars $0.1=\mathrm{mm}$. 


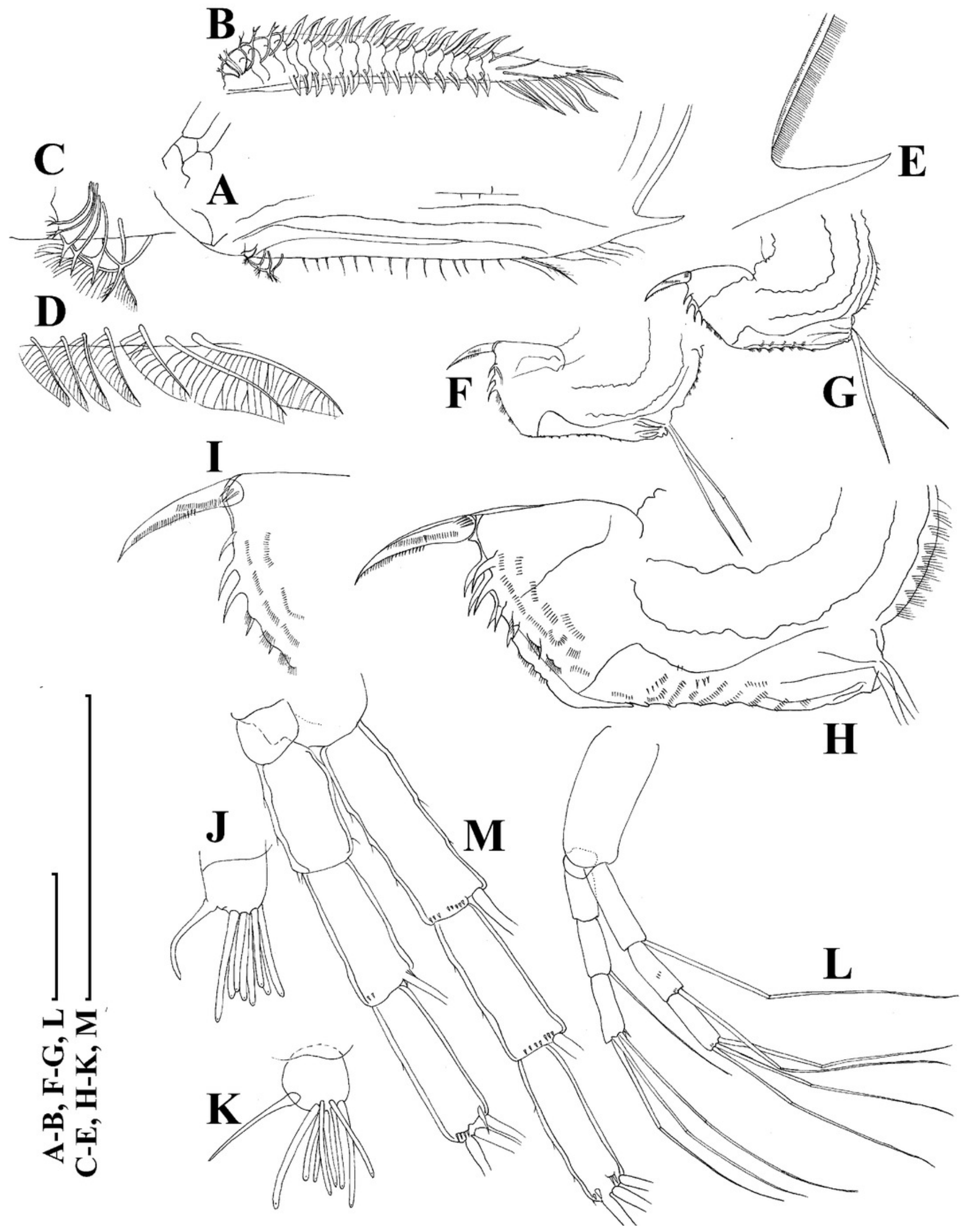




\section{Figure 18}

Scapholeberis smirnovi sp.nov. from the puddle near Lake Maloe Utinoe, Primorski Territory, Far East, Russia.

A-B, Thoracic limb I. C-D, Thoracic limb II. E, Thoracic limb III. F-G, Thoracic limb IV. H, Thoracic limb V. Scale bar $=0.1 \mathrm{~mm}$. 


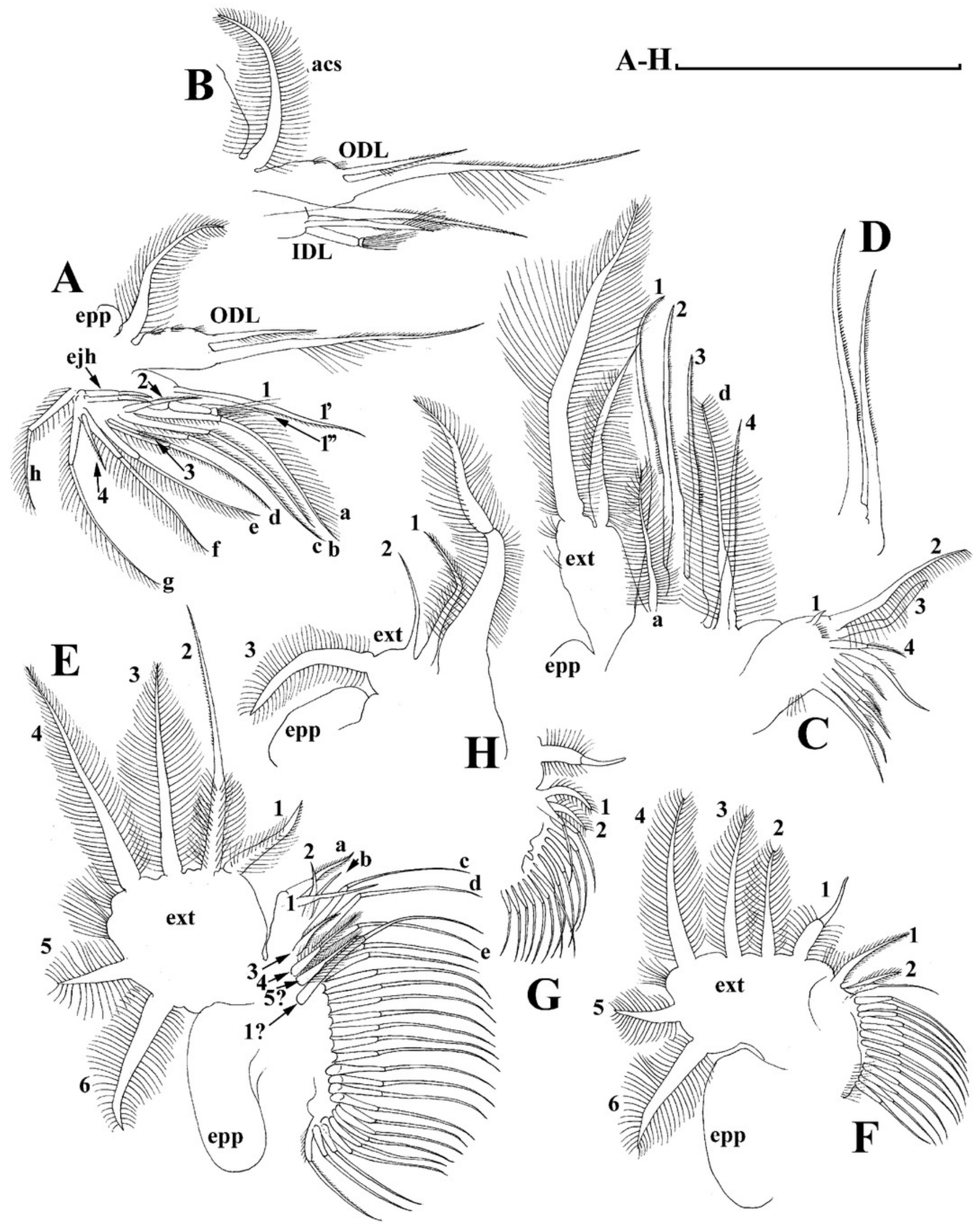




\section{Figure 19}

Scapholeberis smirnovi sp.nov., ephippial and preephippial females from the puddle near Lake Maloe Utinoe, Primorski Territory, Far East, Russia.

A-B, D-F, Ephippial females, C, Preephippial female. A, Ephippial female, lateral view. B, Ephippium, lateral view. C, Preephippial female, lateral view. D, Ephippial female, anterodorsal view. E, Ephippium, anterodorsal view. F, Ephippial female, ventral view. Scale bars $=0.2 \mathrm{~mm}$ for $A-D, F, 0.1 \mathrm{~mm}$ for $E$.
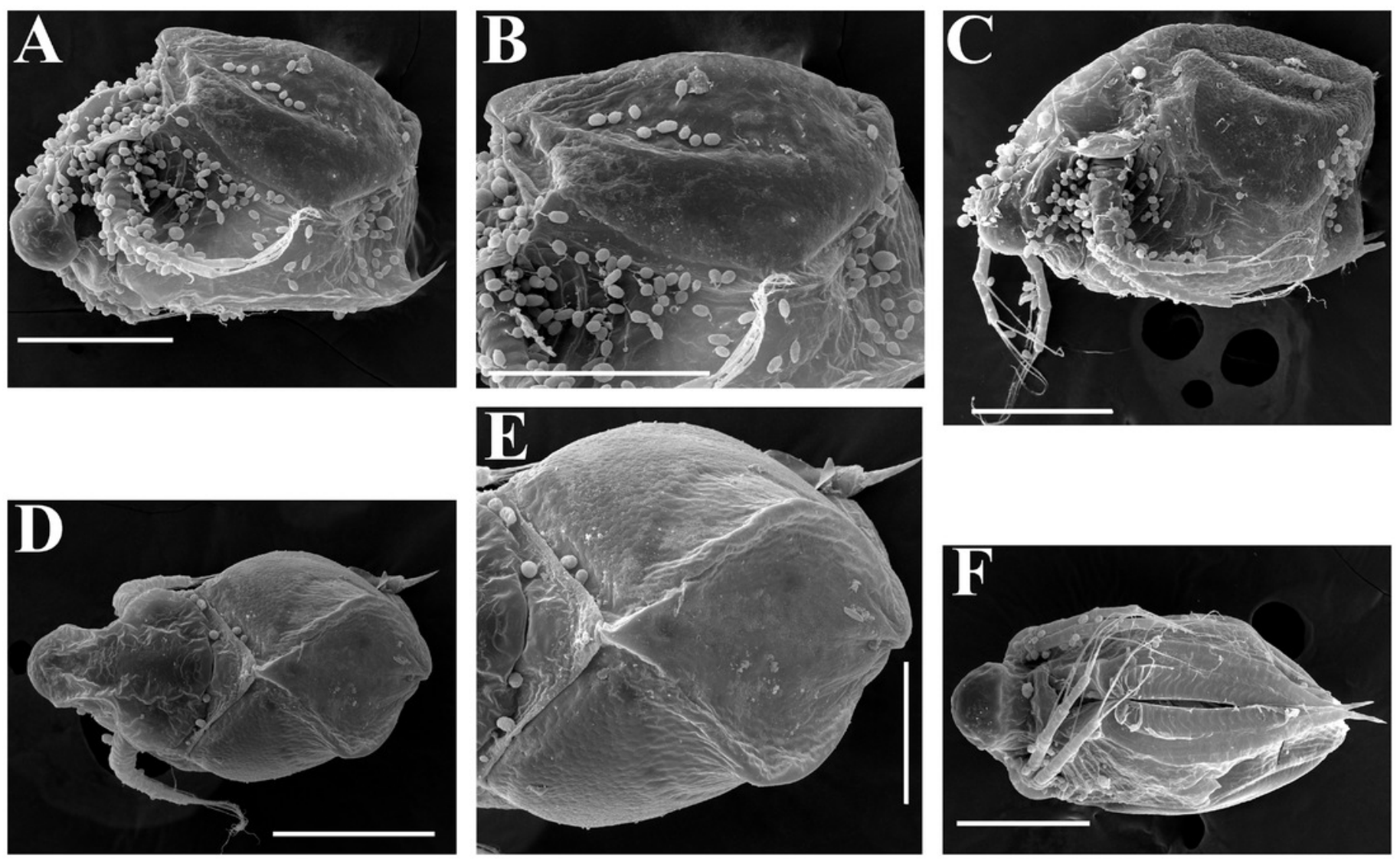


\section{Figure 20}

Scapholeberis smirnovi sp.nov., ephippial females from a pond in Choenggye Mountains, Seoul, the Republic of South Korea.

A, Ephippial female, lateral view. B-C, Head, lateral view. D, Ephippium, lateral view. E-F, Ornamentation of ephippium. G, Ephippial female, dorsal view. H, Head, dorsal view. I-J, Ephippium, dorsal view. K-L, Armature of ephippium on higher magnifications. Scale bars = $0.2 \mathrm{~mm}$ for $\mathrm{A}, \mathrm{D}, \mathrm{G}, \mathrm{I}, 0.1 \mathrm{~mm}$ for $\mathrm{B}-\mathrm{C}, \mathrm{H}, \mathrm{J}-\mathrm{L}, 0.5 \mathrm{~mm}$ for $\mathrm{F}, 0.2 \mathrm{~mm}$ for $\mathrm{E}$. 

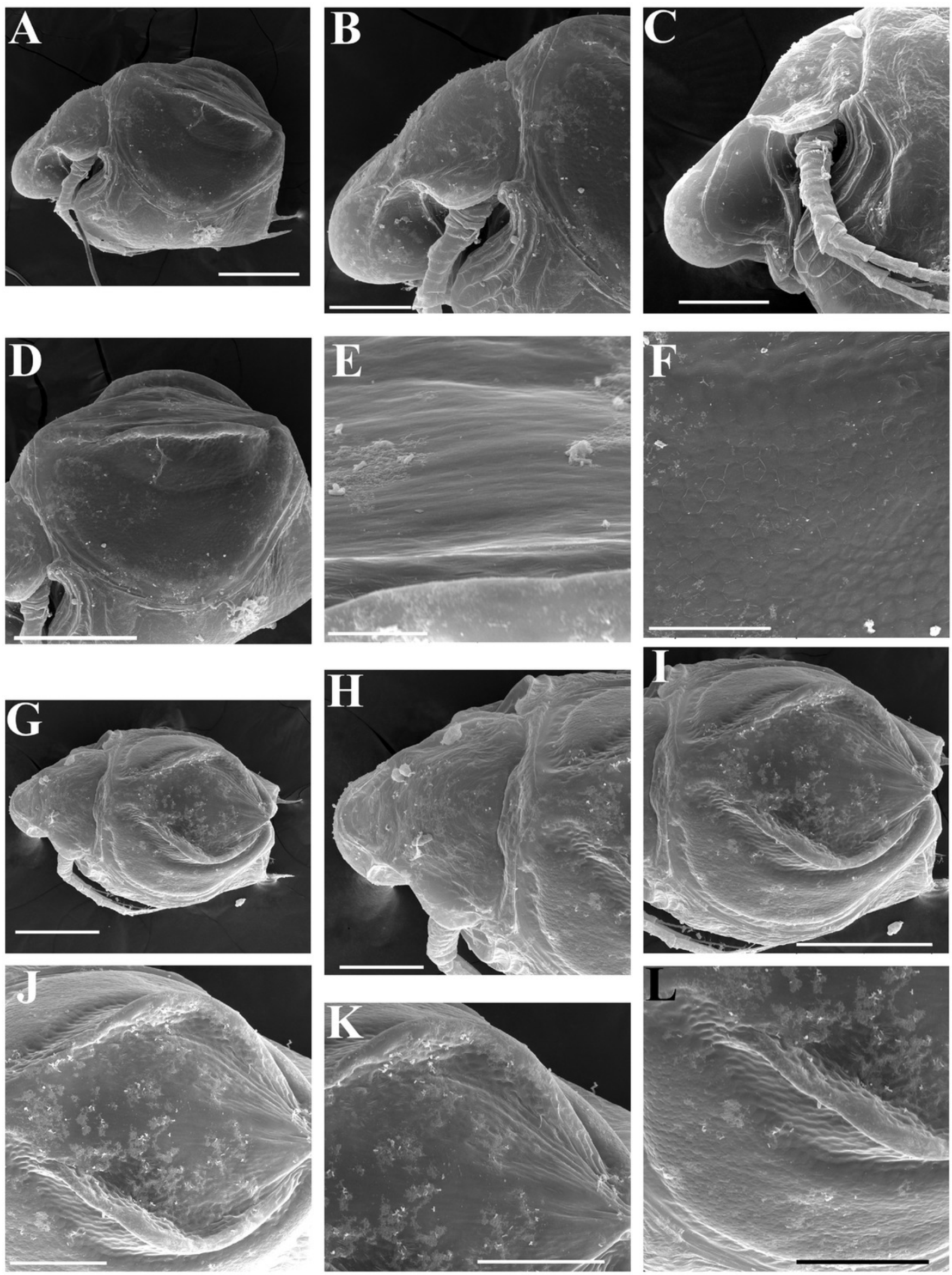
Figure 21

Analysis of identification for four species groups of Scapholeberis based on GenBank data.

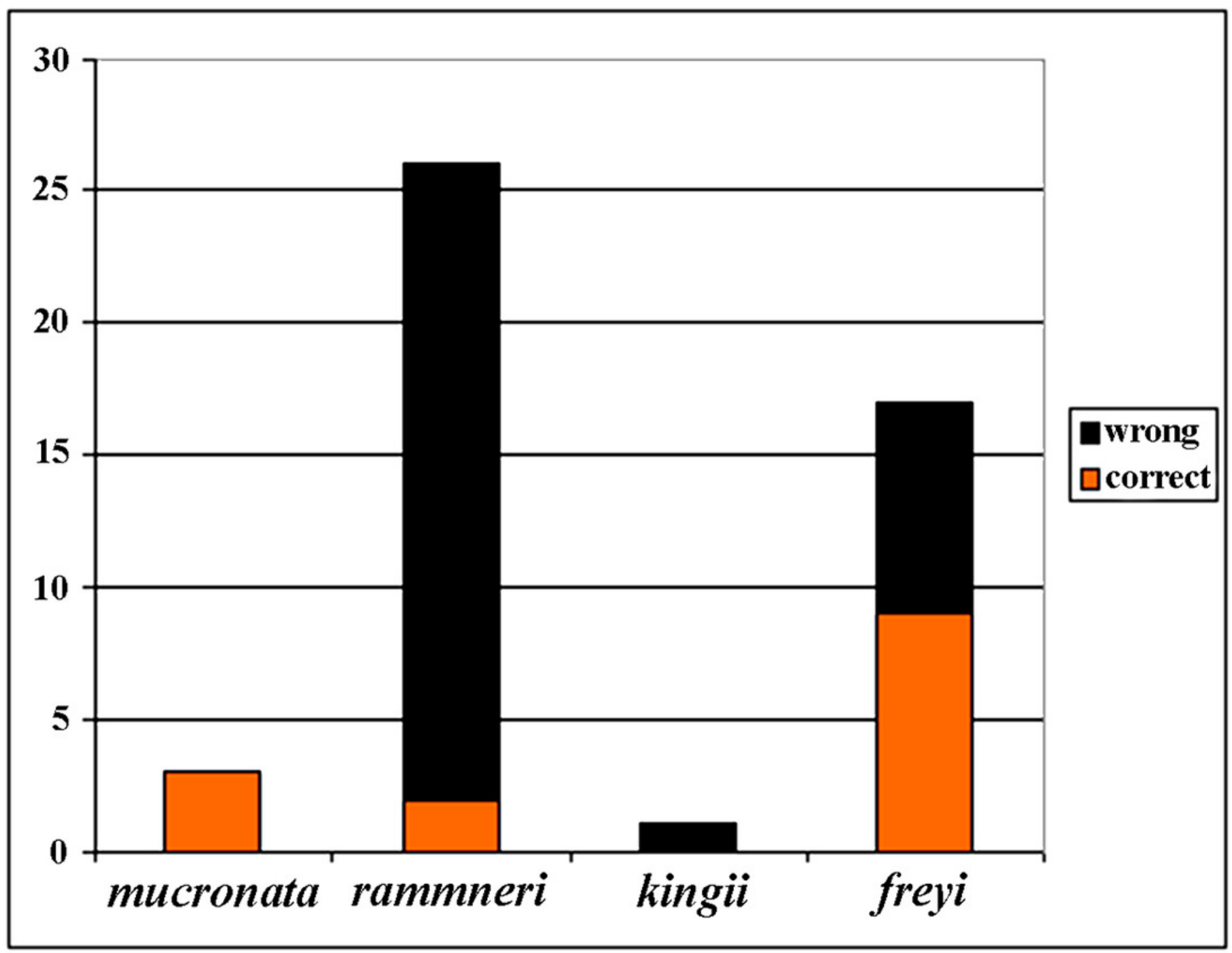




\section{Table $\mathbf{1}$ (on next page)}

Table 1. Differentiation of presently recognised species of the Scapholeberis kingii group in Eurasia based on morphological characters. 


\begin{tabular}{|c|c|c|c|}
\hline Taxon & S. kingii & S. intermedius & S. smirnovi sp.nov. \\
\hline $\begin{array}{l}\text { Rate of distance between } \\
\text { the center of ocellus and } \\
\text { eye to distance from the } \\
\text { center of ocellus to the } \\
\text { tip of rostrum }\end{array}$ & almost 2 & almost 3 & about 5 \\
\hline $\begin{array}{l}\text { On thoracic limb I, the } \\
\text { ratio between seta } 1 \text { ' and } \\
\text { seta } 2\end{array}$ & $\begin{array}{l}\text { almost } 2.5 \text { (i.e. seta } 2 \\
\text { is relatively short) }\end{array}$ & $\begin{array}{l}\text { almost } 1.5 \text { (i.e. seta } 2 \text { is } \\
\text { relatively long) }\end{array}$ & $\begin{array}{l}\text { almost } 2.5 \text { (i.e. seta } 2 \\
\text { is relatively short) }\end{array}$ \\
\hline $\begin{array}{l}\text { In ephippial females, } \\
\text { area between two keels } \\
\text { of ephippium }\end{array}$ & $\begin{array}{l}\text { strongly elongated, } \\
\text { keels not projected } \\
\text { laterally out of body } \\
\text { dorsal contour }\end{array}$ & Unknown & $\begin{array}{l}\text { strongly rounded, } \\
\text { keels strongly } \\
\text { projected laterally out } \\
\text { of body dorsal contour }\end{array}$ \\
\hline
\end{tabular}

